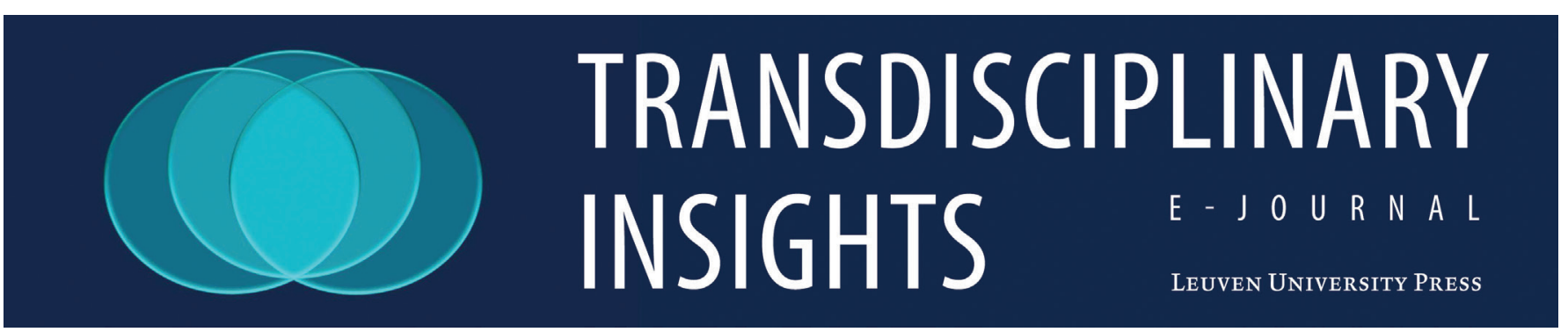

\title{
Facing the Future: A Blueprint for a Resilient and Equitable Society: Connecting the Functional Building Blocks
}

F. Bocken ${ }^{1,2^{*}}$, E. Brennan ${ }^{1,3^{*}}$, N. Claessens $\mathbf{1}^{1,4^{*}}$, D. Claeys $\mathbf{s}^{1,5^{*}}, \mathrm{~S}$. Debeaussaert ${ }^{1,6^{*}}, \mathrm{~T}$. Dubois ${ }^{1,7^{*}}$, A. Franken ${ }^{1,8^{*}}$, B. Vanwyngaerden ${ }^{1,9^{*}}$, J.R. Nova Blanco $^{1,10}$, K. Becher ${ }^{11, \$}$, P. Vandenbroeck ${ }^{11, \$}$.

${ }^{1} \mathrm{KU}$ Leuven-University of Leuven, Honours Programme Transdisciplinary Insights, Leuven, Belgium;

${ }^{2} \mathrm{KU}$ Leuven - University of Leuven, Master student Criminology, Leuven, Belgium;

${ }^{3} \mathrm{KU}$ Leuven - University of Leuven, Master student International Business Economics and Management, Brussels, Belgium;

${ }^{4} \mathrm{KU}$ Leuven - University of Leuven, Master student Physics, Leuven, Belgium;

${ }^{5} \mathrm{KU}$ Leuven - University of Leuven, Master student Digital Humanities, Leuven, Belgium;

${ }^{6} \mathrm{KU}$ Leuven - University of Leuven, Master student International and European Law, Leuven, Belgium;

${ }^{7} \mathrm{KU}$ Leuven - University of Leuven, Master student Linguistics, Leuven, Belgium;

${ }^{8} \mathrm{KU}$ Leuven - University of Leuven, Master student Biomedical Sciences, Leuven, Belgium;

${ }^{9} \mathrm{KU}$ Leuven - University of Leuven, Master student Philosophy, Leuven, Belgium;

${ }^{10} \mathrm{KU}$ Leuven - University of Leuven, Department of Microbiology and Immunology, Rega Institute for Medical Research, Clinical and Epidemiological Virology, Leuven, Belgium.

\author{
${ }^{11}$ shiftN cvba, Leuven, Belgium. \\ *These authors contributed equally to the work. \\ \$Email: kb@shiftn.com, pv@shiftn.com
}

\begin{abstract}
Contemporary society is plagued by a number of issues and inconsistencies on both an environmental and a socio-economic level. Reliance on bank loans forces debtors to seek means to repay their debts, thus facilitating the current boundless economic growth in which long-term, environmental considerations typically come second. On the individual level, since virtually nothing is free, everyone has to ensure his or her own livelihood, mostly in the form of wage labour. For fear of poverty, the unemployed must adjust to the needs of the job market and risk not being able to fully explore their potential. Other socio-economic groups also face stigmatisation, and inequality is rampant as a result of the pervasive market-based pricing mechanisms. In view of these issues, it seems unjustified to accept these terms and conditions in the future, especially since the West has to cater to its ageing population and the ensuing pressure this will exert on welfare systems. Therefore, as a transdisciplinary team assisted by various experts and armed with insights from a wide
\end{abstract}


variety of sources, we propose an alternative model of society based on the values of fairness, inclusion and transparency, with the goal of developing a representative systems map for a future, resilient and equitable society. The exact workings of this society are captured by several building blocks, which together endeavour to cover the full range of functions and responsibilities associated with society today, and jointly promote democratisation while guaranteeing equal political representation for all members of society.

\section{Key words}

Equitable and resilient society, fairness, inclusion, future, Universal Basic Income, social wealth fund, money creation, governmental structure, commons

\section{Challenge Statement \\ Develop a causal loop diagram as a blueprint for a future, resilient and equitable society}

\section{Introduction: Our Current Predicament}

Today's world is undergoing a variety of radical changes. The economic and technology sectors have recently experienced unparalleled and largely unchecked growth, while environmental issues intensify and largescale demographic shifts in contemporary societies imply future complications. While there are local grassroots initiatives to address these global issues, governance structures and policymakers are slow to adapt to this new reality.

The transition that society is experiencing affects every corner of the globe. Advances in automation technology have resulted in the widespread loss of jobs in the manufacturing industry, and as machines become more advanced many other industries may be threatened in the future (Sundararajan, 2017). Demographic changes, such as the ageing population in the West and the incipient problem of overpopulation, will eventually lead to challenges for existing welfare structures (Deboosere, 2018). As for the environment, global warming and the ensuing rise in the sea level threaten both natural and human systems. Climate scientists warn of an impending 'tipping point' after which these negative changes become irreversible (IPCC, 2014). While these external challenges must be addressed by the governments concerned, they also affect economic systems. Unsurprisingly, the economic system is fraught with problems: the economic crisis of 2008 revealed that the current capitalist system is unstable, and there is still no solution for the growing problem of inequality (UN, 2011). Yet another related issue in most western societies is the general increase in public distrust of the government and its institutions, leading to a rise in populism and political extremism (Goodwin, 2018; van der Meer, 2017).

However, emerging global trends and local initiatives give hope for the future. Progress in information technology has enabled the rediscovery of an old form of economic activity, namely that of collaborative production. This economic domain includes the sharing economy, cooperative currencies, and commonsbased peer production. This is in part due to new sorts of goods, services, and production methods, which neither fit the traditional logic of the market nor adhere to the customary managerial hierarchy (EC, 2018). All of this points to a new paradigm, in which individual interests are tied to the common good and vertical hierarchies are replaced by more open, horizontal types of collaboration. Examples of collaborative production include urban farming initiatives in many metropolitan areas worldwide and local currencies, such as the Bristol Pound (Demain, 2017). Another emerging concept in this context is the Universal Basic Income (UBI), which is being tested through pilot programs in a number of countries. While the idea behind the UBI is not new (it was first proposed in the $18^{\text {th }}$ century), it may help in addressing contemporary issues including job scarcity and overly complex and poorly structured welfare systems (IMF, 2017).

That these remedies are valuable in their own right is beyond doubt, yet none can singlehandedly resolve the current predicament. Therefore, it is in the opinion of the authors that there is a need for fresh ideas and viable alternatives to the workings of contemporary society, based on a structured combination of such alternatives. This study introduces a vision for a better future through a schematic 'blueprint,' which is meant to represent a society that combines humanistic values with resilience, adaptability, and equitability. To begin, the next two sections discuss the long history of utopian writing and link it to our interpretation of the equitable society. Section 3 details the methodology we employed to collect insights and necessary information on the relevant topics of inquiry. Section 4 introduces and defines the 'functional building blocks,' or the core 
mechanism and components that support a resilient and equitable society. Section 5 discusses the workings of these building blocks when integrated into the blueprint, and it highlights the key connections they share with other aspects of the model. Finally, section 6 addresses the limitations of this study and points to areas for further research.

\section{The Guiding Vision}

The guiding vision for this project has been to develop a blueprint for a future society that is both equitable and resilient. This project is by its nature related to a long intellectual history of utopian thinking and utopian schemes. The term 'utopian' applies to any social, intellectual, or political scheme which is impractical at the time when it is conceived (Rousseau, 1901). This history of utopian thinking starts with Plato's ancient Republic, in which he proposes a model for a virtuous city, in contrast to other, inferior types of government systems. His virtuous city involves the exclusion of certain ideas and the limitation of private wealth. At the outset of the sixteenth century, Thomas More's Utopia ${ }^{1}$ (1516) would almost completely reverse the utopian vision of Plato. He portrayed a utopian society as an insular state with no private property, no inequality, and no ideological disputes. As such, it promotes pluralism instead of the restrictive measures advocated by Plato. For Marx and Engels, utopias should not simply be the result of a thought exercise or a literary means to critique society, but should instead be perceived as a goal to achieve (Paul, 2017: p. 137). Their Communist Manifesto (1848) refers to More's Utopia, arguably placing More as the first historical writer in the communist, and perhaps even the socialist, movement. In the twentieth century, Rawls' work on social justice and Nozick's Anarchy, State, and Utopia (1974) integrate utopian thinking into political theory. Nozick argued for the 'minimal state,' which is aimed at protecting the liberty of the individual. Rawls introduced his 'ideal theory' and argues for a 'realistic utopia' that focuses on peaceful international relations and human rights (Brown, 2002). His 'ideal theory' acknowledges the necessary societal conditions for a utopian society, while his insistence on his theory being realistic highlights the importance of working towards a better society today.

Similarly to Rawls, this project introduces a vision of society that is slightly idealized but gives meaning to the current initiatives working in that direction. However, we deliberately refrain from proposing a static or fixed masterplan society and the way it should be structured. Instead, we present a coherent set of building blocks to be the driving force behind an increasingly equitable and resilient society. As stated in the introduction, these building blocks figure together in a blueprint designed to be flexible and reactive to whatever relevant changes affect society. Due to the "checks and balances," such as the many feedback loops between stages of decision-making, society is highly complex but also more equitable and resilient. The intended audience are citizens of today's world; we hope to engage individuals, communities, and nationstates to work flexibly towards more equity and resilience. In that regard, a fitting motto for our project is the following adaptation from the Utopian Alphabet ${ }^{2}$ : "utopists with ambition, are supposed to hope to not stay utopists for long." (Abicht, Absillis, \& Aelberts, 2011)

\section{Approach}

Society's intricate and global troubles can be defined as a wicked problem. ${ }^{3}$ For one, there are many contributing elements that cannot be subsumed under one single field of study. Similarly, many stakeholders must be actively involved. Not only should the proposed solutions be open to revision, updating, and improvement but, most importantly, research should be applicable to society's current issues. As demonstrated by Rawls, research in the form of utopian thinking also requires a realistic frame. Such a wicked problem demands a broad way of thinking in order better to understand the interactions between contributing factors and stakeholders. Besides, an approach that takes everything into consideration will also be able to evaluate possible solutions better.

Therefore, such problems cannot be solved by a single discipline and must instead be addressed from preferably a 'transdisciplinary' perspective. ${ }^{4}$ Not only does a transdisciplinary approach combine the insights of various disciplines, yielding a holistic view of the problem, but transdisciplinary research also specifically endeavours to find solutions for the current problems in society. A truly transdisciplinary approach blurs the division between academic fields, and as a result it requires a new way of thinking (Bernstein, 2015; Pohl, Krütli \& Stauffacher 2017). 
To provide this transdisciplinary framework and the insights it may offer, the research team consisted of master students from various academic backgrounds. ${ }^{5}$ Over the course of the study, the team was assisted by two consultants, Kim Becher and Philippe Vandenbroeck, who helped them achieve a transdisciplinary mindset, and who provided insights from systems thinking and design thinking, which are particularly useful when dealing with wicked problems. ${ }^{6}$

At a first stage, the team sought to identify and structure the problem. To do this, the team engaged in a slightly modified version of the 'Actor constellation game,' which helps to identify the stakeholders or societal actors as well as the network they build around the central issue (Pohl, Krütli \& Stauffacher 2017). ${ }^{7}$ This is a crucial process because the identified stakeholders can prove to be part of a viable solution. This exercise yielded to two tangible deliverables: a web of the relevant stakeholders (e.g. government, educators, businesses) and a defined list of overarching values and characteristics that are necessary for any society to be equitable and resilient (for instance, active participation in decision-making by the people in society, and knowledge being freely accessible to all). Ultimately, it provided a general outline of the actors and values that are relevant to the problem, which remained an important source of information throughout the research process. Additionally, it allowed the team to identify which experts and stakeholders to consult for their expertise in order to grasp the problem better. More specifically, the team held interviews with Prof. Dr. Andrew Vande Moere, professor of architecture, Prof. Dr. Antoon Van De Velde (KU Leuven), professor of philosophy and economics, and Prof. Dr. Eric Mathys (KU Leuven), professor of bioeconomics. Each expert offered their insights on the relevant topics for which the team lacked necessary information.

At a later stage, we gathered further material from all sorts of data on the problems societies currently face, and we evaluated current initiatives, local or global, that seek to tackle these issues. In this respect, one particularly informative source of information was the documentary 'Demain,' which shows how pioneering initiatives are currently re-inventing energy, agriculture, democracy, education, and even the economy. ${ }^{8}$ From such sources, we were able to determine which concrete actions could be taken in the future and how these fit into the envisioned blueprint of a more equitable and resilient society.
Furthermore, we compiled insights gathered from the literature on alternative models of economy and governance. In so doing, we endeavoured to consider solutions and arguments from the whole ideological spectrum found in the literature. ${ }^{9}$ Afterwards, the newly-acquired knowledge was synthesised into systems maps with the help of the assisting consultants, who familiarised us with systems thinking through Kumu, a web-based data visualisation platform. ${ }^{10}$ Visualisation through systems maps offers a more nuanced understanding of the interactions between elements (Pohl \& Hadorn, 2008). Each systems map was then analysed in order to extract the values and potential solutions that corresponded best to our interpretation of an equitable and resilient future.

Once these values and solutions had been selected and evaluated, we discussed and decided on the essential components of the envisioned society, i.e. the core machinery of the envisioned society which provides the basic outline of the blueprint. A preliminary version of the blueprint was presented to an expert panel consisting of representatives and stakeholders from the community and academia, Prof. Dr. Jef Peeters and Prof. Dr. Anne Snick. ${ }^{11}$ Based on their feedback, final adjustments were made to the map, producing the final version of the blueprint as displayed in this study. The following chapters describe each of these building blocks found in the blueprint and explain the way in which they interact.

\section{Functional Building Blocks}

The subsections cover the following components: a social wealth fund, a democratic monetary system, universal basic income and basic services, a commonscentric economy, and citizen-led governance. Rather than representing a fixed master plan, the blueprint and its building blocks are intended to remain relevant in a dynamic and increasingly equitable society.

\subsection{A Social wealth fund}

Our first building block, the social wealth fund, aims to democratize and equalize financial citizenship. It is designed to capture and invest public revenue in order to fund social interests and create public wealth. As such, this repository for investment funds represents the component of society on which the other building blocks ultimately rely for their funding. This does not mean that it is more important than the other components, but 
rather that it is necessary to first discuss the workings of social wealth funds.

Existing funds comparable to the present conception of the social wealth fund are either stateowned 'sovereign wealth funds' which invest globally to benefit the national economy, or specific 'social funds', investing in specific local targets which are either community-led or governed by a local institution (i.e. the Local Development Fund in the Republic of Malawi ${ }^{12}$ ). Two concrete examples of a Social Wealth Fund can be seen in the Alaskan and Norwegian governments, which are investment funds of which each citizen is considered to be a shareholder. The Permanent Fund of Alaska was created by a bottom-up initiative in 1976 to save a portion of the state's oil revenue for the future. ${ }^{13}$ Every citizen in Alaska is issued an annual universal basic dividend as part of the Permanent Fund Dividend Program. Likewise, the Government Pension Fund of Norway collects the wealth surplus of its petroleum trade which is used to finance its generous welfare system. ${ }^{14}$ This government pension fund is the domestic branch of the Norwegian Global Investment Fund. It was established in 2006 to manage the government's accumulation of long-term financial assets. Norway's Social Wealth Fund receives the net central government receipts from petroleum activities and returns the amounts needed to finance the non-oil deficit. Another example is the Australia Sovereign Wealth Fund. ${ }^{15}$ As of 2006, this fund has been operating independently of the government and instead relies on a board of members (so-called 'guardians') selected by the ministry. The Australia Sovereign Wealth Fund manages different specific public asset funds with the aim of investing for the benefit of future generations and strengthening the Commonwealth's long-term financial position.

It thus seems safe to say that the prevalence of sovereign wealth funds is increasing globally (IFSWF, 2018). Most strictly governmentally-financed wealth funds comply with a formal set of principles and practices outlined by the International Forum of Sovereign Wealth Funds (IFSWF), called the 'Santiago Principles' (IFSWF, 2018). In practice, local funds are also government agencies set up as semi-independent institutions. These government-financed funds contrast with funds that derive their means from a bottom-up initiative, viz. democratically-financed funds. However, to democratize the funds and allow for more directly involved citizenship, there is need of a different ownership structure from that based on the publicprivate dichotomy.

One possible theory that can provide such an alternative structure of ownership is that of assetbased welfare (Lennartz \& Ronald, 2017). This economic theory proposes a redistribution of productive assets rather than individual income. The acquisition and accumulation of assets can guarantee economic prosperity because the ownership and investment of assets generate a basic income. Traditionally, the poor are forced to spend the majority of their income on consumption and retain very little to save and invest in assets. A social wealth fund that is structured as assetbased welfare acts as the guarantee of assets for every citizen and therefore guarantees a basic assetbased income.

Access to assets for every citizen is linked to access to 'common goods,' which are the natural resources of the planet. In this regard, Pogge T. (2001) criticizes the uncompensated exclusion of the poor from the use of natural resources. His proposal for due compensation therefor is the 'global resources dividend' (GRD). This GRD is to be paid by governments to their citizens, who have an "inalienable stake" in all limited natural resources, and hence the government owes them compensation for monopolizing the resources. Pogge's proposal of the GRD is criticized by Hayward T. (2006), who pertinently states the following:

"allowing states to choose exactly how to raise the requisite funds within their own jurisdiction is recognition of their sovereign rights; requiring them to do so is recognition of their responsibilities as co-inhabitants of a delicately-balanced global ecosystem." (Hayward, 2006: p. 368, emphasis added).

Like the Australia Wealth Fund, the social wealth fund described in this paper would keep funds for immediate socio-economic needs while it would reallocate funds to cover long-term risk management. Hence, the social wealth fund is connected to a different repository, viz. the Risk Fund. The idea of a risk fund is inspired by Ulrich Beck's Risk Society: Towards a New Modernity (1992). He argues that environmental risks are no longer just an unpleasant but manageable side-effect of heavily industrialised societies, but that they have indeed become the most influential and important factors to consider. Like the uneven distribution of wealth in society, the distribution of socioenvironmental 
risks is also skewed. After more than twenty years, this observation is still relevant in discussions on ways to achieve a more sustainable and resilient society. The Risk Fund provides the safety net that serves to preserve environmental resilience. Moreover, the proposed social wealth fund provides the financial basis necessary to support an equitable democracy.

\subsection{A democratic monetary system}

From the big credit crunch of 2008 , it is clear that the current financial system is flawed. Not only must the government keep economic activity in check, but the system is also unstable from a medical, social, environmental and even psychological perspective. Yet, almost ten years after the credit crunch, serious structural reforms have yet to be enforced. Instead, governments have imposed austerity measures on their populations to save the banking system without taking the necessary steps to avoid a similar or worse kind of economic cataclysm in the future. Meanwhile, many layers of society are suffering from the consequences of precariousness and poverty: public services are being cut down, inequality is mounting, trust in authorities and politics is eroding while populism and extremism are on the rise.

Increasing inequality resulting from the current economic system may be tackled by adopting a new monetary system. A look at the history of the European welfare state reveals that the systems in place have predominantly focused on the distribution of existing money and wealth, while the distributive effect of money creation has essentially remained within a blind spot. In fact, there are several direct and indirect channels through which the money system aggravates inequality (Zeddies, 2018).

A fact that is widely ignored is that $90 \%$ or more of the circulating money is currently created by private banks (Positive Money, 2018). Whenever a bank lends money to a person or a business, the bank creates that money, albeit in the form of an obligation to pay back the principal and the interest on that loan. However, the interest is not 'created' together with the principal, which means that the borrower must 'find' it elsewhere. As a result, many debtors have problems paying their debt because there is not enough money in the system. This systemic scarcity results in relentless competition and structural unemployment. To acquire these funds, the economy has to grow constantly, even if this comes with environmental destruction (Lietaer \& Dunne, 2013).

As Lino Zeddies (2018) from the German sovereign money reform organization "Monetative" points out:

"[By enabling] banks to fuel asset bubbles and booms through extensive credit creation into the asset markets... [the current system] creates huge profits for banks, financial markets and 'the haves' in general." (Zeddies, 2018)

The effect described can be aggravated through special accounting practices, like derivatives. If the rules were fair, those profits from bubbles would disappear when the bubble bursts, but in our current system the banks are 'too big to fail' since they must provide most of the money and control the payment infrastructure for the outside economy. Without banks, the current system would collapse entirely (Zeddies, 2018).

Furthermore, the current system also favours big corporations over small businesses: big corporations have the means to set up their own corporate in-house banks, which provide them with a huge funding and liquidity advantage over small companies relying on external funding. The European Central Bank has started to buy bonds from multinationals in order to drive down their costs as part of its Quantitative Easing program, which gives big companies another unfair advantage (Zeddies, 2018).

Another characteristic of today's money is that it is used for very different and often contradictory purposes, namely as a means of exchange, a unit of account, and a store of value. Money that is stored tends to be withdrawn from circulation in order to increase its monetary value. When significant amounts of money are stored, there may not be enough money in circulation to maintain a healthy economy.

In the past, experiences with new types of currency have shown their ability to reduce the sharp inequalities that are inherent of a debt-based money system. One of the most compelling cases is the "Wörgl," a cooperative currency named after the Austrian town where it was introduced in 1931 (Lietaer \& Dunne, 2013). With a third of the able population unemployed, the mayor of Wörgl developed a new currency, based on the principle that money needs to circulate extensively in order to create more wealth collectively. To achieve this, work certificates were distributed, which lost their value if they were not spent before a given expiry date. As a result, the Wörgl circulated 12 to 
14 times more than the national currency. Soon, full employment was a reality and economic activity soared: a bridge was built and the people of Wörgl even started investing in forestry projects to accommodate future generations. Other towns followed Wörgl's example and even French president Daladier paid a visit to the town. This triggering event led the Austrian central bank to assert its monopolistic power in prohibiting the issuing of cooperative currencies like the Wörgl (Lietaer \& Dunne, 2013).

Historically, the power of central banks dates back to the 17th century, when monarchies and bankers formed a powerful alliance (Lietaer \& Dunne, 2013). Monarchs financed their wars through bank debts, which were ultimately paid by the population through taxation. One would assume that, in modern societies, central banks are public entities controlled by the parliament, but this is in fact not the case in many countries: Cédric Frère, the grandson of Belgium's notorious financier Albert Frère, was recently installed in the 'Council of Regents' of the National Bank of Belgium, without prior parliamentary consultation (HLN, 2018). William Alexander of Orange-Nassau was a board member of the Dutch Central Bank before becoming King of the Netherlands. Hence, private and public interests are strongly interwoven in our financial system, especially so in the United States, where it is not uncommon to switch between working for the government, private banks, rating agencies, the Federal Reserve, accounting firms, etc.

In recent years, various civil initiatives have emerged in Europe that advocate a reform of the monetary system to create more wealth, equality, and stability. Examples of such initiatives are 'Ons Geld' (Netherlands), 'Vollgeld Initiative' (Switzerland) and 'Positive Money' (UK). ${ }^{16}$ These initiatives all have in common that they want to put an end to the ability of banks to create money in the form of bank deposits when they make loans. This monetary reform would transfer the ability to create money exclusively to the state, creating what Positive Money has termed a 'sovereign money' system. In this paper, we will not go into detail about what such a system would look like, but we can name a few of its advantages:

"Taking the power to create money out of the hands of banks would end the instability and boomandbust cycles that are caused when banks create too much money in a short period of time. It would also ensure that banks could be allowed to fail without bailouts from taxpayers. It would ensure that newly created money is spent into the real economy, so that it can reduce the overall debt burden of the public, rather than being lent into existence as happens currently." (Positive Money, 2018)

This also means that money could be created and directly transferred, under democratic scrutiny, to places where it is needed and beneficial for the public. To summarize, there are two potential changes to the monetary system that could be implemented within our blueprint. First, a new central bank could feed directly into the social wealth fund and act as a 'partner state' to support cooperative, commonsbased initiatives at all levels of society. Overall, the financial system would become significantly more transparent and easier to govern from an economic perspective. Second, this new 'sovereign' monetary system could co-exist with local, regional, and complementary currencies that would circulate more frequently and would help to strengthen the commonsbased economy, especially since these currencies help to create a better understanding of what money can do for the community. Complementary currencies aim at linking unmet needs with unused resources. By doing this, they create a culture of solidarity and reciprocity, which is also key to making commonsbased initiatives thrive (Lietaer \& Dunne, 2013). While neither initiative is directly represented on the systems map, both potential changes have the capacity to drive equity and financial resilience in society.

\subsection{A Universal Basic Income}

A central component of our model for the future is the Universal Basic Income (henceforth UBI), which would now be perceived as a form of welfare. More specifically, a Universal Basic Income should satisfy the following five characteristics (Basic Income Earth Network, 2018):

1. Periodic: it is paid at regular intervals, not as a one-off grant.

2. Cash payment: it is paid in an appropriate medium of exchange, allowing those who receive it to decide what they spend it on. 
3. Individual: it is paid on an individual basis and not, for instance, to households.

4. Universal: it is paid to all, without a means test.

5. Unconditional: it is paid without a requirement to work or demonstrate a willingness to work.

The idea of a UBI is not new: Thomas Paine (1737-1809) first came up with a 'territorial dividend,' which is a form of compensation every citizen ought to receive in exchange for being born after most things were acquired as private property by predecessors (Paine, 2013). ${ }^{17}$ While the idea has not always been popular since it was first formulated, the growing issue of inequality, on both a local and a global scale, brought to the fore by Thomas Piketty with his influential 'Capital in the Twenty-First Century' (2014), has inevitably rekindled debate on the viability of a UBI. As Victor Hugo famously said, there is nothing as powerful as an idea whose time has come.

In his paper 'Why surfers should be fed', Philippe Van Parijs states the following:

\begin{abstract}
"a defensible liberal theory of justice, that is, one that is truly committed to an equal concern for all and to nondiscrimination among conceptions of the good life, does justify, under appropriate factual conditions, a substantial unconditional basic income." (Van Parijs, 1991)
\end{abstract}

As an argument in favor of UBI, he mentions that it would help people out of the unemployment trap ${ }^{18}$ while simultaneously improving the life quality of people with low-paying jobs. Moreover, it would massively redistribute income from men to women, who are still overrepresented in occupations without pay, such as child care and elderly care.

Ironically, it is only when an occupation entails revenue that it is considered to be useful, which in turn justifies why it should be remunerated. From this perspective, one could suggest that the UBI permits lazy people to remain lazy or, put differently, that people will inevitably exploit this opportunity without contributing. However, payment does not entail that a given job contributes to society more than any other occupation per se. In this respect, the anthropologist David Graeber published his theory on so-called "Bullshit Jobs" (2018): jobs that do not necessarily contribute to society. Similarly, the fact that an occupation does not entail a livelihood does not mean that this occupation is without value. As a result, the exact demarcation between true "work" and what is considered more of a hobby so to speak is rather vague and arbitrary. For instance, being a babysitter can be a full-time job, yet being a babysitter does not, a priori, involve more skills than being a stayat-home parent.

Providing a UBI to all individuals would indeed make it a lot easier to choose (or to remain occupied in) jobs that do not yield significant revenue. Instead of being obliged to adjust to the needs of the market, the individual will be able to enjoy whatever occupation he or she likes, without having to sacrifice financial autonomy.

Although it is unwarranted to prevent people from accumulating capital in order to provide for the next generation - from a moral standpoint, that is (see Rand, 1967) - in other words, some justified inequalities will remain, the UBI ensures that it is unnecessary to accumulate this wealth to begin with, as the UBI offers freedom and opportunities in itself. In view of these undeniable advantages, it is no wonder that Van Parijs thinks that "basic income is one of those few simple ideas that must and will powerfully shape, first the debate, and next the reality, of the new century," (Van Parijs, 2004: p. 8). Van Parijs argues that until now, there has only been one unmistakable instance of an implemented Universal Basic Income, the Alaska Permanent Fund Dividend, which was created in 1982, and provides every Alaskan a dividend amounting to an average of $\$ 1200$ a year, in a lump sum (Van Parijs, 2004).

However, there are a number of common objections or arguments against a universal basic income. For one, one may find it unfair to grant everyone, including lazy yet able-bodied individuals, a basic income which is financed through the taxation of working individuals (Elser, 1986). Another closely-related matter concerns the costs of introducing a UBI: if the UBI is financed with taxation money levied on labour, then enough people must be willing to contribute. If not, the cost of implementing the UBI may simply be too high. ${ }^{19}$ Another key concern with the UBI is that it could discourage people from working. ${ }^{20}$ As for the latter concern, studies on Win-for-Life winners suggests that even when livelihood is assured, people choose to keep on working (Marx, 2018). ${ }^{21}$

At present, research is in the process of weighing the pros and cons of the UBI. ${ }^{22}$ For example, a study conducted in Finland in Kela, in which 2000 unemployed 
participants each receive a monthly payment of $€ 560,-.^{23}$ The researchers at Kela hope to investigate how social security can be restructured to address the changing nature of work and to promote active participation and provide a stronger incentive to work while reducing bureaucracy. Originally, the research project, which is due in 2019, was more ambitious until the Finnish administration agreed on a more modest version. Admittedly, this project does not qualify as a true UBI. The amount is relatively small and cannot be considered viable, the participants were homogeneous to the extent that they were all unemployed, and the experiment is for a limited duration of two years, all of which contradict the full definition of a $\mathrm{UBI}$, as stated above. Hence, the research endeavour has already been criticized because it is inherently incapable of yielding relevant results concerning the UBI. ${ }^{24}$ Nevertheless, the researchers are convinced that the experiment can yield valuable insights into UBI.

\section{The co-existence of a UBI and the 'care economy'}

Among 'nondiscrimination' in respect to conceptions of the good life, the UBI provides citizens with the opportunity to leave the workforce and care for their loved ones. This will create a universal social insurance program through which families can access elder care and childcare. Eligibility for this program is not someone's income or assets, or the availability of family care providers; it is actually on functional need.

Next to the individual benefit, this adaptation of the system is a huge saving to the health system as a whole, e.g. emergency care visits and readmissions to hospitals can be abandoned because there are more home and communitybased supports in place (Gupta, Brown \& Gingerich, 2017). Another means of reducing the workload of practitioners is to develop a digital platform where experts give professional advice to patients in order to reduce the number of real-time consultations, which are part of the Universal Basic Services (UBS) and as such are financed by the government. Additionally, such digital platforms improve transparency and health literacy, given that patients may be advised by more than one professional on which step to take next.

In view of the ageing population in the West, it is essential that helping older adults who are marginalized can contribute to an increase in social engagement. By increasing social solidarity and decreasing social burden, lower health care costs are obtained, and a workforce decrement is prevented from happening as the population ages. The latter has positive influences on society; whereas workforce decrement is associated with the involuntary isolation of the elderly from society and subsequently leads to increased health care costs and demands on social services (Kim \& Belza, 2017).

An example to promote solidarity in elderly care is demonstrated by The Fureai Kippu welfare system in Japan, in which people earn credits for caring for the elderly, which they can save for themselves as they age, or transfer to other family members (Hayashi, 2012). In the Netherlands, on the other hand, students can live in nursing homes and provide 30 hours of volunteer work per month in exchange for free accomodation (Jansen, 2015).

That people are actually fearful of aging into poverty, and that families feel they do not have the means to support their aging loved ones, is not acceptable, so it should not be accepted.

\subsection{A commons-centric economy}

An equitable and resilient society is one that has the flexibility to accommodate economic shifts, allows individuals the freedom to pursue the work of their choosing while encouraging an economic environment that provides social and environmental benefits. In this respect, one of the most important components of an equitable and resilient society is the 'commons economy'. In broad terms, a commons is a community of people who share a resource. Access to the resource in question is regulated by rules agreed upon by the community (Bauwens, 2017). In this sense, commons are autonomous in that they not only represent both demand and supply, but also adopt the function of market regulator. The focus on community entails that a commons goes beyond a strictly economic model and must instead be conceived of as an essentially social organisation. As such, the commons represents a means to create both economic and social value, since it is based on cooperation rather than competition. From an economic perspective, a commons-based economic model differs radically from the current economic model, where supply and demand rule over pricing mechanisms, which in turn are linked to profit, investments and the rate of production. 
From a conceptual point of view, the traditional economic model is extractive. By purchasing a given product, the buyer has obtained the right to possess said product, i.e. to make it part of his or her personal capital. Closely related to extractive economic models is the notion of scarcity (Bauwens, 2017). As the name indicates, scarce materials (so-called 'heavy products' in Bauwens, 2017) are limited by definition, which justifies an extractive model. As product supply is partially determined by its degree of scarcity, the price is directly affected by the availability of the product. Hence, scarcity can be a good indication of what a product or service is worth, which further lends support to extractive market-based pricing mechanisms. Nevertheless, the technological developments of the past century or so have given rise to so-called light products (Bauwens, 2017). Light products, like software, are not scarce as they can be copied indefinitely, nor do the creators incur more costs with each distribution. For the sake of progress, it is undesirable that such products should be artificially withheld from the public domain through extractive pricing mechanisms. Luckily, a commons-centric society (Bauwens, 2017) aims to make as many services and products as possible available in the public domain. As a result, extractive models are replaced by generative alternatives, and a market with economic actors becomes a network with users and contributors.

Perhaps the greatest achievement of the commons is that it endorses a social organisation that is based on cooperation, transparency, and intrinsic motivation. Whereas not everyone possesses the same information in hierarchically-structured, value-creating structures, commons strive to spread knowledge and information to all members (Bauwens, 2017). Since commons are a priori universally accessible, such transparency in the distribution of information is encouraged to ensure better management and decision-making.

In contemporary society, time spent working for a salary is valued more than time spent otherwise. To give a concrete example, a stay-at-home parent is not remunerated for their time, whereas a babysitter obviously deserves payment for doing an arguably less elaborate job. Moreover, individuals see themselves forced to work jobs they would rather not do in order to ensure a livelihood. In this case, the salary becomes the main reason why someone chooses to spend time working. The motivation is extrinsic as it results from the fear of poverty and the desire to acquire money. By contrast, peer-to-peer communities distinguish themselves from profit-seeking firms in that the so called 'commoners' (Bauwens, 2017) are by no means required to contribute. Rather, members choose to contribute as they wish. Hence, their contributions are driven by intrinsic motivation ${ }^{25}$ (Bauwens, 2017). In the long run, the differences between profitable work and hobbies or occupations would become irrelevant and with it, the current stigmatisation against non-salary work.

The more optimistic generative and unbiased approach of peer-to-peer communities, combined with their appeal to intrinsic motivation, is able to dominate in those sectors where both peer-to-peer communities and extractive competitors occur. The example of Wikipedia comes to mind: because of Wikipedia's accessibility to contributors from the general public, it has an insurmountable competitive edge over the Encyclopaedia Britannica. Likewise, the successes of Über and others reveal the potential of peer-to-peer communities, although Über is, strictly speaking, an example of netarchical capitalism (Bauwens, 2017). Typically, netarchical capitalists such as Über and Facebook make a profit off a platform that accommodates value-creation through peer-to-peer activity (Bauwens, 2017). Ideally, all value created by peer-topeer participants should be used to further facilitate and promote peer-to-peer activities. Nonetheless, these netarchical capitalists clearly dominate the competitors that do not exploit peer-to-peer technology (Aslam \& Aqib, 2017), which again hints at the potential of the commons.

Our blueprint proposes a hybrid value-creating model, in which the commons is not the only avenue for valuecreation; the model also leaves room for economic actors to create value according to the principles of scarcity. Ideally, commons-based activities would be responsible for comparatively more economic activity than scarcity-based ones, so that one could truly speak of a commons-centric society. Nonetheless, a fully commons-centric society seems unlikely, due to three concerns that hinder the expansion of the commons. A first problem relates to how commoners are meant to ensure their livelihood if their work immediately becomes part of the public domain without remuneration. In the blueprint, the solution to this problem is considered in the form of a Universal Basic Income (UBI). 
By means of pre-distribution rather than redistribution (Bauwens, 2017), basic services and a monetary amount are given to all members of society so that peer-topeer initiatives are supported.

The second, more challenging question deals with the adaptability of the commons for products that are indeed scarce, which have come to be termed heavy products (Bauwens, 2017). For one, it is difficult to imagine how certain heavy products and the corresponding economic sectors could be commonified on a large scale. Even if a given heavy product is indeed available through a commons in the public domain, other problems may arise. These can in principle easily be prevented by determining how much of a shared resource may be consumed without jeopardizing the resilience and the availability of the resource over time. For instance, peer-to-peer communities that deal in heavy products are susceptible to falling prey to the so-called 'tragedy of the commons' (Hardin, 1968), which occurs when the individual members consume more than they should, i.e. without regard for the needs of the other members and the future generations. Additionally, for many heavy products, it is also necessary to determine what level of joint consumption is most reasonable from an ecological point of view. It seems obvious that ecological considerations should determine joint consumption, which regulates consumption by the individual members.

Finally, the question arises whether supply can meet demand in a truly commons-centric society and whether it is justified to leave demand unsatisfied. Say, for instance, that a famous and well-liked celebrity fully shaves his head. As a result, it is now trendy to shave one's head, and all of a sudden, the demand for razor blades soars. The commoners who are incidentally responsible for razor blades, a scarce (or heavy) product, do not feel like producing more, and so demand remains unsatisfied. Admittedly, this is a trivial example, but the question is much more pressing if farmers, for instance, decided not to meet demand. With the hybrid economy portrayed in the blueprint, the problem does not occur: if the commons cannot meet demand, the potential profit to be made from this market will attract businesses which operate according to principles of scarcity. If for some reason, the scarcitybased fraction of the economy is unable to react on the incentives of demand, which then remains unsatisfied, the government can step in to import the required product or to fund its production with means from the
Risk Fund. Admittedly, when exactly it is justified for the government to step in to satisfy demand remains to be determined, but it seems intuitive that in the case of insufficient food production the government intervenes, whereas it is more debatable whether the government should cater to fashion.

However, our model accommodates this tension by creating a flexible system of value creation, incorporating both the commons and traditional economic structures, which are better suited to deal with scarce products. While the ultimate aim of this future society would be to 'commonify' increasingly more sectors, money-motivated businesses would remain in place for those products and services that are better suited to traditional economic structures. Once the UBI ensures that wage labour is optional, people will have the freedom and flexibility to take part in the value creation system that best suits their needs, aptitudes, and motivations. Moreover, money-motivated firms are taxed in order to sustain the Social Wealth Fund, whereas commons-based contributions, i.e. work that directly benefits everyone, would be exempt from taxation, unless commons sold for profit outside a defined community. ${ }^{26}$ Additionally, Creative Commons licensing or an adaptation thereof would prevent competitive businesses from patenting and exploiting inventions that have appeared on the public domain as a result of peerto-peer activity (Creative Commons, 2017).

Moreover, an economic model that encourages commons is better suited to accommodate the incipient automatisation in many sectors. Currently, automatisation is not always a welcome development: less labour force is required, with more competitivity and unemployment as a result. By contrast, the commons are generative, and by consequence they strive to provide products and services to everyone for no cost. Automatisation does not entail poverty, since it is prevented by the UBI, but simply redounds to more efficiency in providing products in the public domain. Commoners can instead deal with other pressing issues. This highlights the cooperative and evolutive nature of the commons-centric society: once a problem has been dealt with, society jointly deals with the next problem on the way to prosperity for everyone.

Clearly, the hybrid model strives to become more commons-centric over time: activity by the commons is not taxed, participation is made possible thanks to the $\mathrm{UBI}$ and it appeals to intrinsic rather than extrinsic motivation. Admittedly, this seems to force people to engage in activity by the commons, although it is 
admissible that some individuals may strive to pursue a successful career. In fact, it would still be entirely possible for individuals to strive to attain this goal in the scarcity-based fraction of the economy which still functions with wages. Nonetheless, two remarks are in order. For one, the drift towards a more commonscentric society entails that ultimately all but the most resilient and scarcity-driven heavy products would be produced by the commons. Hence, individuals who seek to pursue a career have limited options, so these individuals may not be fully satisfied with the sector in which they work. However, there is no reason to pursue such a career to begin with: if most things are freely available in the public domain, and buying power becomes less important, there is no advantage to accumulating personal capital.
The more challenging problem, by contrast, is how such an economy would interact on an international level. For the heavy products, the aspect of community in the commons inherently calls to mind rather smallscale, local groups. Admittedly, a drastic change towards a commons-centric society may yield surprising results in terms of productivity and efficiency, yet it certainly seems more intuitive that it should lead to less economic exchange between countries if these countries maintain the current economic models, since production no longer aims for profit and instead seeks to cater to national demand first and foremost. On the other hand, commons may very well overproduce, in which case foreign transactions may form a good outlet for overproduction and an additional means to finance the various funds.

\section{‘Commonsense’ Drug Pricing Policy}

Currently, research on drugs is conducted by private pharmaceutical companies which are funded either by the government or by their own profits from selling popular drugs such as Zoloft (Vaidhyanathan, 2017: p. 59) which they are able to sell at artificially high prices since they hold the patent and, by extension, the exclusive rights to rule over pricing, distribution and manufacturing of their drugs (Vaidhyanathan, 2017: p. 12). Technically, these prices are not justified, since the government funds private research from taxation, so that the population has already covered the costs of developing the drug. If, on the other hand, the government plays no role in funding research, pharmaceutical companies are forced to keep their prices high if they wish to have the funds necessary to conduct research on new drugs. As a result, the pharmaceutical sector is characterised by a so-called 'patent thicket' accompanies an increase of commonsbased activity, which in turn entails that more services and products are available in the public domain. Hence, the Universal Basic Income will decrease over the development of the commons-centric society. (Vaidhyanathan, 2017: p. 47), or more fittingly, 'tragedy of the anti-commons' (Vaidhyanathan, 2017: p. 48). Patent thickets occur when researchers of different pharmaceutical companies are unable to share their knowledge due to technology being protected by the many patents, which eventually slows down progress towards better drugs, and more importantly, it has led to what economists have labelled the 'welfare loss', i.e. the fact that it has become more expensive to stay healthy due to popular drugs becoming less accessible.

The commons may disappoint regarding the accessibility and pricing of drugs. If drugs are developed, distributed and manufactured by actors in the public domain without patents, fake drugs may circulate freely (Vaidhyanathan, 2017: $p$. 6-7). Hence, patents certainly serve their purpose as a reliable indicator of quality in the pharmaceutical industry. However, the need for a patent does not entail that the pharmaceutical companies themselves should have the exclusive right to distribute. Rather, there are two alternative ways more fitting to our model of society which ensure affordable qualitative drugs while catering to demand. On the one hand, further research on less common diseases should not be funded by private companies through revenues from important, yet basic drugs, but rather by the government itself, which would fund and stimulate its universities and research laboratories to invent new drugs while retaining the exclusive right to produce and distribute the drugs at fair prices. As the government has other sources of income, it is not forced to raise its prices artificially. ${ }^{27}$ Besides, if funds are directed to a limited number of laboratories or universities, knowledge is less fragmented so that progress is quicker, while also ensuring that the negative effect of the patent thicket, viz. high prices, does not occur. A second, perhaps complementary possibility is to grant prizes and grants to the research organisations (including commons) that have solved certain health-related issues for which the government grants monetary remuneration (Vaidhyanathan, 2017: p. 53) while retaining the exclusive right to distribute the invention. Practically, the state cannot provide cheap access to all types of drugs because patents hold on a supranational level, i.e. beyond the boundaries of the proposed alternative society, so that some products will probably have to be imported at higher prices. 


\subsection{Universal Basic Services: an equitable education system}

In addition to the Universal Basic Income (UBI), all members of society are given Universal Basic Services (UBS), which represent an additional building block of the equitable and resilient society. Whereas the UBI hands a monetary amount to all citizens, the UBS offers them access to various kinds of services, ranging from healthcare, education and transportation to legal services. Often, a minimum amount of education and free or affordable health services are considered to be fundamental human rights (Ports, Reed \& Percy, 2017; Troncoso, 2018). Many countries offer such basic services to a certain extent: most provide education free of costs up to a certain age, and some countries already offer universal health care. Which services the UBS may cover while remaining affordable is yet to be determined, but it seems uncontroversial that basic education be a representative part of the package. Moreover, education plays a crucial role in society, which is why this subject is highlighted in this section.

Indeed, the very future of any individual is heavily influenced by their education. If all members of society are given more or less equal opportunities for education, equality can severely diminish in the long run. In our society, a fraction of the Social Wealth Fund would serve to finance public education. While it is beyond doubt that an equitable education system is necessary, the question arises as to what exactly constitutes equity in education, and how to best implement relevant policies.

In conversations about equitable education, the terms 'equity' and 'equality' are sometimes used interchangeably but, as Espinoza argues, the concepts must not be confused:

\footnotetext{
"The 'equity' concept is associated with fairness or justice in the provision of education or other benefits and it takes individual circumstances into consideration, while 'equality' usually connotes sameness in treatment by asserting the fundamental or natural equality of all persons." (Espinoza, 2007)
}

It is unlikely that all children would receive the exact same education and opportunities, and the UBS is not so ambitious as to completely nullify individual differences. Instead, the public educational systems should try to minimize these differences as far as possible through equitable solutions.
For education to be considered equitable, it must be both fair and inclusive. As defined in an OECD Policy Brief, education is fair when "personal and social circumstances - for example gender, socio-economic status or ethnic origin - should not be an obstacle to achieving educational potential," (OECD, 2008). Fairness goes beyond mere equality: whereas equality (only) entails that everybody be given an education regardless of personal or socio-economic circumstances, fairness also takes into account the cultural and historical context of the child's environment. On the other hand, inclusion implies that all individuals be educated to a certain minimum level. For example, all students should be able to read, write, and complete simple maths (OECD, 2008).

It is an immense challenge to implement both conditions into education policy effectively in a way that functions as desired, i.e. as a means to promote fairness and inclusion without adverse effects. Moreover, whatever solution is found now will be outdated in fifty years: as the sociocultural environment changes, so does education. Be that as it may, it seems intuitive that education models that are sensitive to individual children's needs should be more successful at providing an equitable education.

The documentary Demain looks into a Finnish school where children's success did not rely on standard teaching methods and tests. Instead, teachers modify their style of teaching to fit the needs of the student, who might prefer a kinetic approach to learning. Moreover, teachers tried to create a closer bond with their students, for instance by eating lunch with them. Hence, each student receives an education more or less tailored to their learning preferences. Additionally, the learning program of the Finnish school also pays more attention to values, expression, the process of learning itself. Hence, education can also acquaint students with concepts such as equity, diversity, resilience and civic responsibility while encouraging a critical mindset. Indeed, the students of today should be the responsible citizens of tomorrow. They should be aware of their role as members of a democratic society. The lottery-based representation in the policy system (see 4.6 on citizen-led governance) also requires citizens to be informed about the structure and history of their government.

Furthermore, individuals should be self-reliant to some extent, i.e. they should be able to sew, cook, or execute simple repairs. Education should also teach health 
literacy (see below), financial responsibility and respect for the environment, which should offer students a deeper understanding of the world that surrounds them.
The final and most important asset of the 21stcentury citizen is the faculty to adopt a critical mindset: continuous reassessments enable society to continue improving.

\begin{abstract}
Integrating health literacy into basic education
Health literacy goes far beyond knowing facts about good health; it implies people's cognitive, behavioural, and societal skills and abilities to access, understand, appraise, and apply health information (Sørensen, J. et al., 2012). Its importance is increasingly recognized as research has revealed a correlation between limited health literacy and poor health status. As a result, many attempts have been made to build a comprehensive and integrated conceptual model of health literacy. This model can be used as a tool to help develop interventions that enhance health literacy and in doing so, these interventions promote a healthy lifestyle and support the practice of healthcare and disease prevention (Sørensen, J. et al., 2012).

Because the degree of health literacy of the individual is determined by numerous diverse factors, any comprehensive, systemic model of health literacy should take these stakeholders into account. In the proposed society, professionals from health and social care services would be supported by other stakeholders. With respect to health literacy, for example, the educational sector plays a role in assisting professional caregivers indirectly. Moreover, a part of the responsibility is carried by communities, which can range from immediate care given by the family members, to large-scale organizations that help provide the required medical attention of all sorts, possibly in the form of a commons, as detailed in the healthcare box under section 4.3 on the UBI, entitled "The co-existence of a UBI and the "care economy". Due to their recognized status as stakeholders, they would have the possibility to help enhance overall wellbeing and rectify current imbalances or injustice in the healthcare system.

An example of a local initiative to improve health literacy is the Healthy Eating for Young Children (HEY!) programme. HEY! is a project which seeks to improve the future health of children in families who live in the most disadvantaged areas by promoting healthy eating to their parents and by promoting Skills for Life learning (Roberts, 2015). ${ }^{28}$ Such Life Learning skills include literacy, numeracy, the importance of healthy eating and the effects of a proper diet towards the improvement of future behaviour and concentration skills. Such a skill set would allow disadvantaged communities to have more opportunities in the future (HEY project). These Life Learning Skills are taught through practical activities and group discussions in children's centres. An evaluation of the HEY! Programme revealed that parents and caregivers had indeed become more knowledgeable about matters of health as reflected by their checking of food labels.
\end{abstract}

\subsection{Citizen-led governance}

As outlined in the previous sections, the proposed model of an equitable and resilient society unconditionally provides individuals with a Universal Basic Income and Universal Basic Services. The recipients of these services should enjoy enough financial freedom to be exempt from the obligation to work for a livelihood. By virtue of the UBS, the basic life necessities of each citizen, including food, shelter and some insurances, should also be covered. The regulation, distribution, and implementation of the UBI and the UBS is led by a policy system (Walker, 1998: p. 14).

This policy system consists of various bodies with different responsibilities. The bodies not only depend on each other system-internally, since they must also continuously adjust themselves and the policies they push to system-external factors, i.e. they must be flexible with their policies so as to accommodate factors that cannot be controlled through the authority of the bodies, such as natural disasters. Due to this inherent flexibility and the adaptability of policies, the society the bodies represent should be able to deal with all sorts of influences because its policy-system is designed to be resilient (Walker, 1998: p. 8-9).

Strictly speaking, all stakeholders in a certain matter would be guaranteed political representation. On the micro level, the individuals that represent the stakeholders would be selected through a lottery system (Walker, 1998; Van Reybrouck, 2017). The individuals that are selected and wish to be active in policy-making do not jeopardize their livelihood because their expenses are covered by the UBI and the UBS. As a result, decision-making is led by the members from within society who are assisted by experts rather than 
by professional politicians. The reasoning for what policies are ultimately implemented is guided by interaction and cooperation between the stakeholders or, more specifically, their selected representatives. Moreover, a bottom-up lottery system allows the stakeholders with most experience in a certain issue, but without professional political background, to offer their insights and solutions (Van Reybrouck, 2017: p. 44-5). Nonetheless, individuals picked through lottery may, of course, decline this responsibility, in which case another potential representative is selected.

The proposed multi-body system with representativeness based on lottery originally derives from Van Reybrouck, who designed a blueprint for what he considers to be a legitimate government (Van Reybrouck, 2017). Van Reybrouck suggests that the selected representatives should be compensated for their efforts, although it is possible that intrinsic motivation suffices to draw volunteers. A citizen jury is legitimate because it promotes representativity while reducing corruption (Van Reybrouck, 2017; Espejo, 2017). "Government of the people, for the people and by the people" is the adage to live by (Espejo, 2017: p. 42).

\section{Responsibilities}

\section{a) Capture-signals body}

A flexible policy-making system is required because society is in constant flux, provided society in its totality is considered to be a very complex system shaped by interacting factors which may counteract each other and which, as a result, prevent society from attaining a balance or state. Because the contributing factors not only affect society in isolation, but also make other elements fluctuate, it seems intuitive that society is never static. More concretely, ecological, technological, demographic and economic developments continuously disrupt the status quo. If policy fails to adapt to ongoing change, the long-term resilience of society is jeopardized because policy covers other core aspects of the society portrayed, among which the UBI and the UBS (Walker, 1998; Harari, 2011).

Therefore, the policy system should be able to keep track of the fluctuating factors thanks to a body designed for this purpose. Simply put, this capturing body can be said to be attentive to the signals that changing factors emit. Future predictions on the basis of present cues or signals are customary in economics.
The members of this body are picked by lottery and assisted by experts in order better to interpret the meaning of signals. The body then gives feedback on the basis of the captured signals and their implied consequences to the body devoted to the revision and evaluation of implemented policies. In other words, the capturing body and the "policy-revising" body (cf. infra) are linked directly to ensure such an exchange of information and feedback (Walker, 1998: p. 64).

\section{b) Revision body}

In principle, the policy-revising body intervenes when the captured signals call for an adjustment. It consists of a main body and various sub-bodies dedicated to the different essential mechanisms of society, such as the UBI, UBS etc. Such policy adjustments can come in all shapes and forms, but they all aim towards more optimal policies in the present and for the future by focussing on the resilience of the revised alternatives (Walker, 1998; p. 11).

The revision of existing policy or the introduction of a new policy is a two-step process. First, the sub-bodies capture the signals relevant to their component. ${ }^{29}$ Once the signals have been interpreted and the problems have been identified, these individual bodies put forward policy reforms, which are then considered together by the main body that endeavours to reach a compromise between the desired revisions for each building block of society. The revisions also directly influence how the means of the Social Wealth Fund are allocated among the components (Van Reybrouck, 2017: p. 1345). This plan is transmitted to the following body, which is responsible for the final vote on the revision plan, and as such it represents the final step before implementation.

In addition to reports from the body that captures signals, people who are not part of that body can appeal to the revision body for problems that have escaped the capturing body. In Hasselt, a city in Belgium, CitizenLab allows people to contribute their ideas to make public spaces more attractive based on their impressions and needs. ${ }^{30}$

Again, the members of the revision body are drawn by lottery and assisted by experts in the relevant fields, who have expertise in education, economics, healthcare etc. The experts lead the discussion and play the role of mediator between non-expert stakeholders and representatives. 


\section{c) Voting body}

Because implementation ultimately depends on a board of representatives selected by lottery. Hence, it is the citizen rather than the professional politician or policy-maker who determines whether a plan forwarded by the revision body becomes implemented. To ensure responsible decision-making, revision plans should be sufficiently transparent. Ideally, the final vote should take the form of a simple yes-or-no question. Crucially, the contents of the revision plan, i.e. the proposed solutions themselves, should not be the object of discussion at this stage of policy-making, in order to prevent favouritism, lobbying and peer-pressure from threatening voter independence (Van Reybrouck, 2017: p. 135). Additionally, a new board of voting representatives is selected each time a revision plan is presented. In Scotland, for instance, a citizen jury participates in discussions on health-care issues (Scottish Health Council, 2018).

Because different stakeholders, often characterized by contradicting motives, are in principle equally represented politically, it would be difficult to attain unanimity. Hence, for a policy to be implemented, it should be approved by at least to two thirds of the members (Walker, 1998: $p$. 66). If a revision fails to reach the required majority, it is sent for review to the capturing body, which will reevaluate it with respect to the signals before the policy-revising body is given new instructions.

Nonetheless, this discussion of policy leaves several gaps unaddressed. For instance, how accepted revisions are to be implemented and enforced, or how many voters are required to guarantee proper representation of each stakeholder remains in the dark for now and requires more empirical testing (see Carson et al., 2004). Furthermore, social media are said to influence public opinion and indirectly, policy-making, but the exact details of this influence must also be left to future research (Espejo, 2017: p. 42).

\subsection{Law and governance}

\section{Checks and balances}

The governance of the envisioned society seeks to maintain a strict division between the judicial, legislative, and executive organs (or 'bodies'). ${ }^{31}$ Although this division is often attributed to Montesquieu's $D e$ l'esprit des lois (1748), Montesquieu did not suggest that these powers should be divided. Rather, he recognized and highlighted the need for these powers to be balanced (Foqué et al., 2009: p. 347). If there are strict divisions between the three powers, then the division is also found in the organs that represent these powers. By contrast, the way in which the law is applied in the society at hand is more flexible. Hence, the law must not necessarily be applied in a word-byword fashion if a more equitable solution can be attained with a little tweak in the interpretation of the law. For instance, the judges of administrative bodies enjoy some discretionary powers that allow them to act on a case-by-case basis, which often results in a verdict considered more equitable and fair to the general public. Besides, if the law were to be applied literally, both the legislating and the implementing organs would face difficulties. The legislator cannot appeal to general clauses, because every clause should be able to cover all possible scenarios, while it should be sufficiently specific to be functional and efficient according to the implementing body.

Nonetheless, such discretionary powers come with much responsibility and authority, which may have dire consequences if these powers are used incompetently or with evil intent. Hence, the judge or the administrative body concerned should not decide autonomously. Instead, the verdict will first be reviewed by two additional instances, which must also support the decision. Because the judicial system is based on checks and balances, the judicial organ as a whole is held accountable for any decision made contra legem, i.e. a verdict that violates the law in some respect according to some other law. In addition to the system-internal checks and balances, the public also guards against unfair verdicts. In fact, it is through a diagnosis of public opinion that the fairness of a passed judgment or a new law is assessed (Beyens \& Vanhamme, 2008: p. 350).

In sum, the law is an instrument that helps to regulate society, but it does so in a way that promotes fair treatment where it is justified. For such a system to be resilient, the verdicts must be the results of the proper balance between (i) the adaptability of the law and (ii) the different checks that hamper or encourage the proposed verdict, viz. the public and the two additional bodies that validate the decision by the judging instance.

\section{Law of the Commons}

The commons-centric economy of this hypothetical society is not free from the influence of the judicial, 
legislative or executive powers. This section focuses on the benefits proper policy-making can have for the commons. Three points are relevant in this respect.

First, legislative power can provide the legal frame necessary for the commons to be universally accessible, and to formulate a legal definition of a commons on the basis of certain characteristics. Guaranteeing legal access to the commons, entails that the commons cannot discriminate against any potential candidate. Otherwise, they are no longer defined as commons, because they do not evince the core characteristics of a commons, namely transparency and universal accessibility. Hence, legislative power ensures that the commons remain unbiased and by extension, it redounds to more equitability for society as a whole (Bollier, 2015). ${ }^{32}$

A second aspect of judicial power that protects the commons is intellectual property law, which provides legal boundaries to the use of ideas. At present, being the creator of a revolutionary idea often comes with financial benefits, thanks to their exclusive right to market their invention as they see fit. Although intellectual property law is often invoked to create or maintain a monopoly, it does prevent the invention from being exploited. In a commons-centric society, where the boundary between private property and the public domain is blurred, intellectual property law can protect the commons and their inventions. Otherwise, any idea by the commons would quickly be exploited by businesses of the scarcity-based fraction of the economy. More concretely, intellectual property should be designed in such a way as to permit the exchange of knowledge and information while protecting the original inventor. A successful open source initiative that resembles intellectual property law and that encourages the spread of information while acknowledging the wishes of the inventor, is the Creative Commons Licences ${ }^{33}$ by Larry Lessig, which allow the inventor to choose which aspects of property rights he or she wishes to retain in a modular fashion. ${ }^{34}$

Finally, the commons can be protected through a so-called legal generality, a legal concept first introduced by Ann Carette in 1997. A legal generality is a property regime, composed of rights and obligations, which is meant to protect the environment and the goods and services it provides. ${ }^{35}$ More specifically, it obliges individuals and the government to respect the environment. If this obligation is violated, compensation is due, which is spent into rebuilding the damaged ecology. In order to safeguard the existence of the biosphere, the regime and the protection they offer would remain a part of governance, on top of the existing rules for the different aspects of ecology as it were. Concretely, the concept of a 'legal generality' introduces a property regime that serves as an overarching structure. Its protection rules would come on top of the already existing rules of each individual component of the ecosystem.

\section{Bringing It All Together}

\subsection{Overview of the map}

The functional building blocks that constitute the core of the envisioned society interact with each other. All components are designed to be flexible and selforganizing, which contributes to the resilience of society as a whole. For example, the yellow zone on the blueprint, which represents the value-creating elements $^{36}$ in the model, embodies the hybrid economic sector which leaves room for the currently prevailing scarcity-based pricing mechanism and market economics, while also facilitating and encouraging commons initiatives. Although, most occupations, products and services should become commonified in the long run, the system is supposed to allow a flexible exchange of value-creating activity between the economic models. Another component that is developed to be resilient is the proposed system of governance, which is characterized by a bottom-up approach to political representation and an unbiased voting mechanism.

In addition to its resilience, the society was designed with an eye on equitability. In this respect, the Universal Basic Income is meant to allow each member of society to dispose of their time as they think to be valuable. Similarly, the Universal Basic Services provide additional security as they include basic health services etc. As to equitable political representation, the unbiased selections of citizens in governance further democratizes the political sphere.

The blueprint can be explained by focussing on three main areas of the map:

1. The policy loop (blue), which consists of the capture-signals body, the revision body, and the voting body. This loop captures the way in which society is governed. 


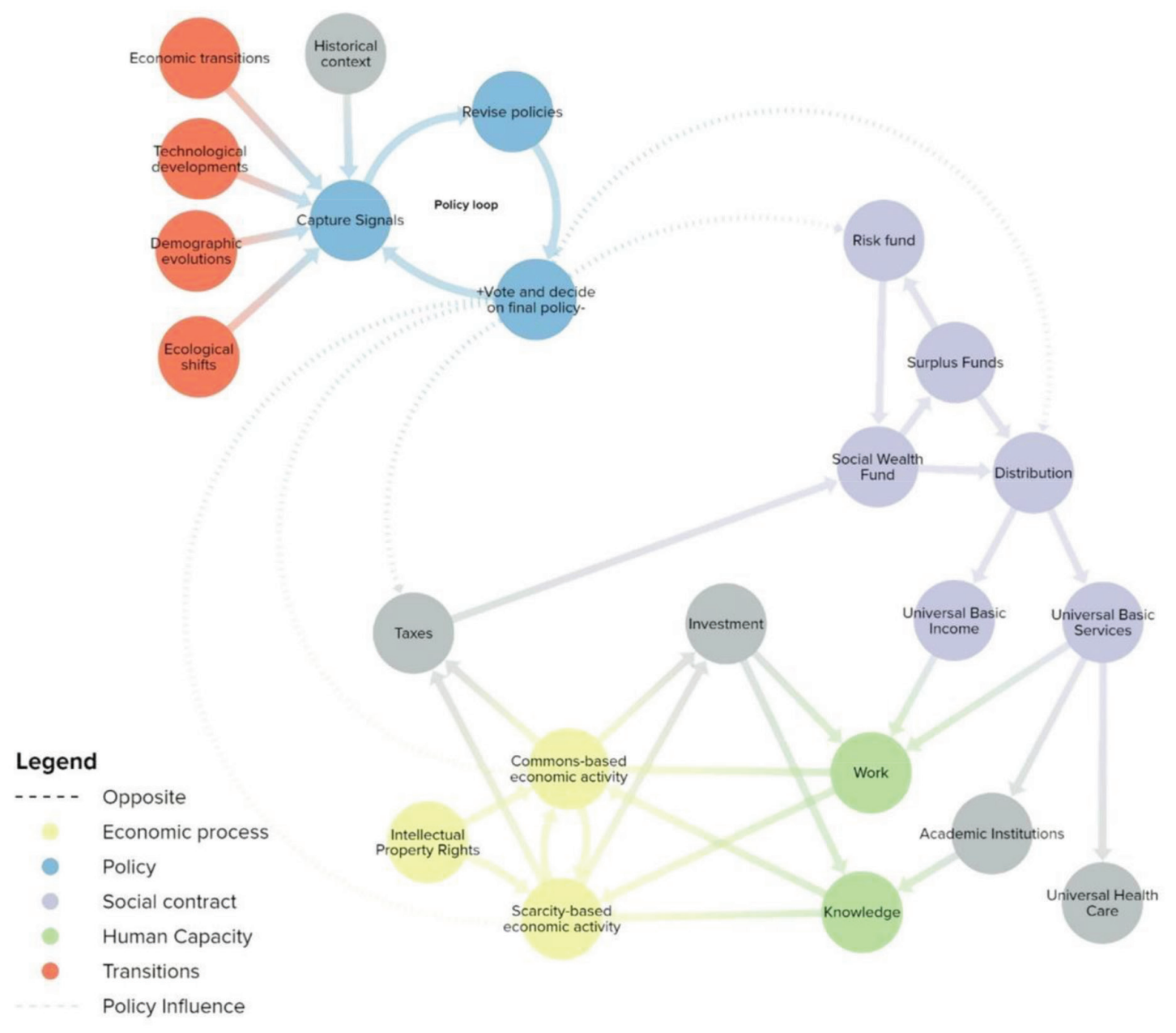

2. The 'social contract', which is represented by the social wealth fund, the risk fund, the surplus fund and the way in which money is distributed. This part of the blueprint is meant to tackle social issues and problems of equitability in society.

3. The economic cluster (yellow) which incorporates commons-based and scarcity-based activity. This loop is responsible for the creation of value.

As is often the case with systems maps, the elements are not all linked by the same kind of connection. Hence, the three sections, viz. the elements they incorporate, do not share the same types of interaction in the blueprint. For the elements of the social contract, the arrows refer to a flow of effort. The value-creating cluster of the map is characterized by connections that represent the exchange of activity between economic models. The dotted arrows of the policy loop are meant to display the encompassing influence of governance on the system. Furthermore, the blueprint also considers the influence of society on policy and governance, by incorporating 'Historical context' as a contributing factor, and through the factors in red. First, we explain how the policy loop is linked to the other sections of the map. Then, we describe how the social contract and the value-creating elements are connected. Together, these two aspects of the map highlight the most crucial features and values of the society portrayed.

\subsection{Policy Loop}

The use of 'loop' in this context does not really correspond to how loops are normally found in systems maps, viz. as 'reinforcing loops' or loops that have a dynamic of their own. In this policy loop, by contrast, the connections represent the flow of the signals from their capture until they have been integrated in a revision plan that is accepted by the voting body. If the voting body rejects the proposition, i.e. if more than a third of 
the voting board refuses the revision plan, it is again submitted to the body that captures signals, effectively completing the feedback loop. The multitude of different bodies and the feedback loop ensure that a proposition to revise policy has been reviewed by many stakeholders and experts before being implemented. Hence, the policy system derives its resilience from the many checks and balances it incorporates.

The policy loop and its bodies are meant to be flexible and self-organizing, which enables society to quickly adapt to external influences. In practice, the bodies are resilient because they are composed of the citizens concerned, selected through lottery each time a new vote takes place.

Such a bottom-up approach to leadership and policymaking not only ensures more political representation for all stakeholders involved, but it also enables society to be informed of incipient problems as soon as they arise, thanks to knowledge acquired by otherwise unrepresented stakeholders and members of society, tackling the issue of inequality in the process. Nevertheless, the citizens are assisted by experts in policy-making, who play a mediating role between stakeholders in the discussion while ensuring that the process of decision-making proceeds smoothly and efficiently.

Directly or indirectly, the policy-making procedure influences virtually all of society, which is represented by the dotted arrows between the policy loop and the other essential components. It is safe to say that the opposite also applies: society exerts an influence on policy-making. This influence is accommodated by the structure of society in two ways. For one, individuals who were not selected to become political representatives, but who wish to report an issue or concern that escaped the signal-capturing body, can directly address the revision body. Secondly, the capturing body is directly affected by the element glossed 'historical context', which can be taken to correspond to the influence of culture on the system of governance.

\subsection{Financial Freedom}

Currently, it is necessary to have an income if one wants to escape poverty and the consequences thereof. As a result, individuals are coerced into unsatisfactory jobs through the dynamics of the job market. By contrast, respecting the fundamental freedom of the individual constitutes one of the core values of the society portrayed by the blueprint. This principle is meant to prevent individuals being led by desperation due to their financial situation. Rather, the individual is free to dispose of his or her time as desired, leading to intrinsic motivation driving productivity, thanks to the Universal Basic Income and the Universal Basic Services. Both these components significantly reduce inequality in society, because they impart equal opportunities to all members of society, who are now able to devote themselves to an occupation that is fulfilling and that best suits their goals and abilities.

In the blueprint, this flexibility is embodied in the economic cluster of the map and its connections. Here, the arrows refer to flows of resources, i.e. monetary flows and the flows of activity in hours that are spent contributing to value-creating activity. The former type applies to arrows such as the one that links the commons-based and the scarcity-based economic models to the element named 'Taxes'. By contrast, the arrows that link both types of economic models represent a fluctuating complementary exchange between models with respect to economic activity, i.e. 'working' hours and investments spent in the respective economic models.

\section{Gaps \& Future Research}

After grasping the complexity of the issues plaguing society, the research team sought to identify which mechanisms could be implemented to address and solve these wicked problems, which were then brought together in a schematic representation of what is designed to be a resilient and equitable society. Nonetheless, a number of topics and issues were not addressed in this study. Obviously, the ambitious goal of the study does not permit an in-depth treatment of all relevant aspects but, more importantly, there simply is no one-size-fits-all solution to any wicked problem: every initiative may have both intended and unintended consequences regardless of its intention.

Our research includes many gaps with respect to the implementation of the proposed alternatives, especially so with regard to the society's governmental and economic structure. Moreover, some of these mechanisms, among which the Universal Basic Income, the Social Wealth Fund, and a large-scale commons-centric economy, are yet to be tested empirically. While collaborative forms of valueproduction would thrive in a society that provides the necessary legal framework and legal protection, it 
remains unclear how commons are to manufacture and distribute certain scarce products. Moreover, the question arises as to how the commons, which do not seek profit, would be stimulated to satisfy demand; or whether the commons should be taxed, provided they have a revenue. Due to the spread of collaborative production, research will probably address these blind spots in the near future.

As for the UBI, many academics and economists have discussed its potential benefits and drawbacks, yet there is still a distinct lack of real world examples: to our knowledge, only one program comes close to satisfying the conditions of UBI. ${ }^{37}$ Therefore, many questions relating to its implementation and the consequences it may have remained unanswered. More specifically, the effects of a large-scale implementation of the UBI on productivity and motivation cannot be predicted with certainty. By extension, the same applies to social wealth funds.

Whereas the former gaps are intrinsically linked to research on wicked problems, the complexity of the issue and the limited scope of the study resulted in a second source of topics on which the team lacked information. For example, while we discuss economic reforms and policy programs at length, there is little attention for social issues, ${ }^{38}$ and only indirect consideration of environmental factors. ${ }^{39}$ Discussions on international policy, by contrast, do not figure in this study altogether.

Yet, these aspects equally contribute to the complex issue at hand. Therefore, our modular approach to an equitable and resilient society is highly simplified, as it focuses on a domestic scenario. Nevertheless, this paper hopes to represent an important step towards designing a future society that is both equitable and resilient. As mentioned in the opening section, no single field of expertise can single-handedly tackle any wicked problem, especially one that involves designing a society from scratch. Nonetheless, the challenge from which the incentive to research this topic derives will stimulate a different transdisciplinary team of graduate students to pick up where we left off and to keep improving our utopian model of society in future years.

\section{Supplementary Materials}

1) Original Challenge Document "BANK OF TRANSDISCIPLINARY CHALLENGES",
KULeuven Transdisciplinary Challenge submission form

2) Symposium Presentation: Transdisciplinary Insights Challenge, "Our Current Predicament", 4 July 2018.

\section{Notes}

1 Full title in Latin De Optimo Reipublicae Statu deque Nova Insula Utopia.

2 Originally Dutch Utopisch Alfabet: honderd toekomstvisies.

3 Wicked problems are defined as problems that "defy complete definition and cannot be solved using existing modes of inquiry and decision making. Moreover, no final solutions for such problems are possible since any resolution generates further issues." (Bernstein, 2015)

4 "Transdisciplinarity" should not be confused with "multidisciplinarity" or "interdisciplinarity", which do not involve as much exchange between the disciplines involved.

5 Programs of study: Philosophy, International Business, Linguistics, Digital Humanities, Criminology, Physics, International and European Law, and Biomedical Sciences.

6 Kim Becher and Philippe Vandenbroeck are part of the core team at ShiftN and work on a wide range of projects as researchers, facilitators, and systems thinkers.

7 Contrary to the customary actor constellation game, there was no role-playing involved.

8 For more information see: https://www.demain-lefilm. com/en/film

9 The books read are the following: A. Atkinson, Inequality. What can be done?; A. Rand, Capitalism: The Unknown Ideal; D. Van Reybrouck, Against Elections; J. Rifkin, Zero Marginal Cost Society; T. More, Utopia; N. Georgescu-Roegen, The Entropy Law and the Economic Process; P. Van Parijs, Just Democracy: The RawlsMachiavelli Programme; Plato, The State; T. Sedlacek, Economics of Good and Evil

$10 \mathrm{https}: / / w w w . k u m u . i o /$

11 Jef Peeters is Emeritus Professor Social Philosophy Ethics at the KU Leuven, Anne Snick is freelancer at SAPIRR, board member of Club-of-Rome EU Chapter, and founding member of Arne Loosveldt Fonds.

12 For more information see: http://www.ldf.gov.mw/l df-programmes/led/

13 For more information see: https://apfc.org/

14 For more information see: https://www.regjeringen.no/en/ topics/the-economy/the-governmentpensionfund/id1441/ 
15 For more information see: http://www.futurefund. gov.au/

16 See references for websites.

17 Thomas Paine, 'Agrarian Justice' pamphlet published in 1797

18 The unemployment trap occurs when being unemployed is more advantageous than working a low-paid job, which leads to people trying to remain unemployed for as long as they can (https:// en.wikipedia.org/wiki/Welfare_trap)

19 See Richard Pereira, 'Financing Basic Income: Addressing the Cost Objection' for an elaborate discussion on this topic.

20 See Damon Jones \& Ioanna Marinescu, 'The Labor Market Impacts of Universal and Permanent Cash Transfers: Evidence from the Alaska Permanent Fund.' for further discussion on this topic.

21 Win for Life is a Belgian lottery game. As the title implies, winning guarantees a life-long income (https://www.nationale-loterij.be/nl/onze-spelen/ win-for-life).

22 Experiments running in 2018 are: Ontario Canada, 6000 participants receive up to 17000 dollars per year on a monthly basis; In the Netherlands cities (Groningen, Wageningen and Tilburg) make social benefits unconditional; In the USA a Silicon entrepreneur, Sam Altman, plans to give 1000 people 1000 dollars a month for a five year period; In Kenia there is a village whose inhabitants receive cash payments from charity organisation Give directly; in Finland the Kela experiment.

23 See www.kela.fi for more information.

24 If the participants know that in two years they must again seek work for fear of poverty and lack of a sustaining income, it is perhaps more likely that they see the experiment as a short-term opportunity for an easy income, since they cannot truly devote themselves to their non-lucrative vocations over two years' time if they know that they will ultimately wind up on the job market again.

25 Admittedly, there may be reasons other than the fear of poverty or precarity that may drive people to work against their will. For instance, stigmatisation may still affect those who wish not to contribute, so that they are again pressured into working against their will. However, our society addresses the problem of stigmatization in other ways. Therefore, I assume that intrinsic motivation is the main cause of contributions.

26 Admittedly, fewer traditional money-accumulating firms directly entail fewer taxes and consequently less capital in the Social Wealth Fund. However, this is not per se problematic since the decrease of firms

27 The Doha Declaration on TRIPS and Public Health (cited in Vaidhyanathan 2017: p. 65-66) declares that governments already have the right to produce cheap versions of necessary drugs when they are unaffordable. Examples are drugs that treat HIV, tuberculosis and malaria. See http://www.who.int/medicines/areas/ policy/doha_declaration/en/ for more information.

28 In addition to promoting the importance of healthy eating, another such skill would be literacy or basic mathematics, which is aimed at bettering the chances of disadvantaged communities.

29 It is beyond the scope of this paper to discuss how a classification of signals can best be made, but this can be arbitrary: categorizing the signals is a matter of methodology and must not necessarily have any empirical foundation.

30 For additional information see: https://www.citizenlab. co/blog/cases/hasselt/

31 The legislative power "makes" the law, the executive power covers its implementation, and the judicial power controls and regulates the execution of the law.

32 "People in the thirteenth century arguably had stronger legal rights to subsistence and survival than people do today. Thanks to Magna Carta and its companion document, the Charter of the Forest, people had guaranteed legal access to the forest to gather firewood, water for drinking and planting, acorns for their pigs, the right to hunt wild game and collect fruit, and much else" (Bollier, 2015).

33 For further information see: https://creativecommons. org/about/

34 Another example is Stallman's idea of open source software and the creation of the General Public Licence.

35 In theory, there are 4 types of property regimes: (i) private property, which is said to belong to a private instance; (ii) common property, which belongs to everybody equally, like sunlight or the air we breathe; (iii) public property, i.e. goods and products monopolized by public authorities; and finally (iv) open-access property, which refers to things that have no owner yet, such as wild animals (Guerin, 2014).

36 "Value-creating elements" would roughly correspond to whatever elements currently produce economic activity. However, 'value' is currently tied to monetary value and for an activity, product or service to be considered valuable, there must often be an economic profit to it (see Section 4.4 on the commons-centric society).

37 This is the Alaska Permanent Fund Dividend, created in 1982 (Van Parijs, 2004) 
38 This includes issues of racial, gender, and sexual orientation discrimination and bias, police brutality, women's reproductive rights, domestic violence, etc.

39 While global warming was mentioned as part of the problem, and some initiatives will likely have positive effects on this aspect of the problem there are outstanding concerns related to climate change related migration.

\section{References}

"A respectable result for the Sovereign Money Initiative." Vollgeld-initiative, 10 June 2018. Retrieved from: https://www.vollgeld-initiative.ch/english/

Abicht, L., Absillis, K., \& Aelberts, J. Utopisch alfabet: honderd toekomstvisies. De Bezige Bij Antwerp, 2011.

"About basic income." Basic Income Earth Network, 2018. Retrieved from: https://basicincome.org/

"About the Licenses." Creative Commons, 2017. Retrieved from: https://creativecommons.org/licenses/

Achterhuis, H. Het rijk van de schaarste. Utrecht: Ambo. 1988.

Aslam, A. \& Shah, A. "Taxation and the Peer-to-Peer Economy." International Monetary Fund, no. 17/187, 8 Aug 2017. Retrieved from: https://www.imf.org/en/ Publications/WP/Issues/2017/08/08/Taxationand-the-Peer-toPeer-Economy-45157

Atkinson, A. Inequality. What can be done? Cambridge, Massachusetts: Harvard University Press, 2015.

"Australia's Sovereign Wealth Fund." futurefund, 2018. Retrieved from: http://www.futurefund.gov.au/

Bauwens, M. De Wereld Redden: Met peer-to-peer naar een postkapitalistische samenleving. Antwerpen/ Utrecht: Houtekiet, 2013.

Bauwens, M. PEER-TO-PEER: Manifest voor een commons transitie. Brussel: Oikos, 2017.

Beck, U. Risk Society: Towards a New Modernity. Translated by Ritter, M. SAGE, 1992.

"Benoeming Cédric Frère in Regentenraad was beslissing van regering: 'Politiek gekonkel van pure machtspartij'." HLN, 26 April 2018. Retrieved from: https:// www.hln.be/nieuws/binnenland/benoemingcedric-frere-in-regentenraad-wasbeslissing-van-regeringpolitiek-gekonkel-van-pure-machtspartij a339fdee/

Bernstein, J. H. "Transdisciplinarity: A review of its origins, development, and current issues." Journal of Research Practice, 11(1), Article R1. 2015. Retrieved from: http:// jrp.icaap.org/index.php/jrp/article/view/510/412

Beyens, K. \& Vanhamme, F. "Onderzoek naar rechtspreken als sociale praktijk." Tijdschrift voor Criminologie, vol. 51, no. 4, 2008, pp. 350-360.
Bollier, D. "The Commons as a Tool for Sharing the Wealth." Commons Strategies Group, 21 Oct 2015. Retrieved from: http://commonsstrategies.org/ the-commons-as-a-tool-forsharingthe-wealth

Bregman, R. Gratis geld voor iedereen. Amsterdam: De correspondent, 2014.

Briony, H. "What is a sovereign wealth fund." World Economic Forum, 13 Oct 2017. Retrieved from: https://www.weforum.org/agenda/2017/10/ what-you-need-to-know-aboutsovereignwealthfunds/

Brown, C. "The Construction of a 'Realistic Utopia': John Rawls and International Political Theory." Review of International Studies, vol. 28, no. 1, 2002, pp. 5-21. Retrieved from: www.jstor.org/stable/20097776.

Bruenig, M. "A Simple Fix for Our Massive Inequality Problem." The New York Times, 30 Nov 2017. Retrieved from: https://www.nytimes.com/2017/11/30/ opinion/inequalitysocialwealth-fund.html

Carette, A. Herstel van en vergoeding voor aantasting aan niet-toegeëigende milieu bestanddelen. Antwerp: Intersentia, 1997.

“Citizens' Jury." Scottish Health Council, 2018. Retrieved from: http://www.scottishhealthcouncil.org/patient public_participation/participation_toolkit/citizens juries.aspx

Coleman, E. A. \& Liebertz, S. S. "Property Rights and Forest Commons." Journal of Policy Analysis and Management, vol. 33, no. 3, 6 May 2014, pp. 649-668. https://doi.org/10.1002/pam.21766

Deboosere, P. P. "Demographic Challenges of the 21st Century." VUB. 2018. Retrieved from: http://www.vub. ac.be/en/demographic-challenges-21st-century

Demain. Directed by Mélanie Laurent and Cyril Dion. 2017.

EC. "Collaborative Economy." European Commission. 2018, June 29. Retrieved from: http://ec.europa.eu/ growth/single-market/services/collaborativeeconomy_en

Elser, J. "Comment on van der Veen and Van Parijs." Theory and Society, vol. 15, no. 5, 1986, pp. 709-721.

Espejo, R. "Cybernetic Argument for Democratic Governance: Cybersyn and Cyberfolk." Cybernetics: State of the Art, edited by Werner, L. C., Universitätsverlag der TU Berlin, 2017, pp. 34-57.

Espinoza, O. "Solving the Equity-Equality Conceptual Dilemma: ANew Model for Analysis of the Educational Process." Educational Research, vol. 49, no. 4, 2007 , pp. 343-363. DOI: 10.1080/00131880701717198

Foqué, R., Orshoven, P. V., Van Gerven, W., Raymaekers, B., \& Vandeurzen, J. "Debat: De scheiding der machten." Ethische Perspectieven, vol. 19, no. 4, 2009, pp. 346-373. Georgescu-Roegen, N. The Entropy Law 
and the Economic Process. Massachusetts: Harvard University Press, 1971.

Goodwin, M. "New Report: The Rise of Populist Extremism in Europe." Chatham House. 2018. Retrieved from: https://www.chathamhouse.org/media/news/ view/178303 Graeber. D. Bullshit Jobs: A Theory. New York: Simon \& Schuster, 2018.

Graeber, D. Debt: The First 5,000 Years. New York: Melville House Publishing, 2011.

Guerin, K. "Property Rights and Environmental Policy: a New Zealand Perspective." New Zealand Treasury, 1 March 2003, pp. 1-42.

Gupta, S., Brown, D. \& Gingerich, C. "Episode 13: Building the Caring Majority (w/Sarita Gupta)." The Next System Project, 6 Dec 2017. Retrieved from: https:// thenextsystem.org/learn/stories/episode-13-buildingcaring-majority-w-sarita-gupta Harari, Y. N. Sapiens: A Brief History of Humankind, London: Vintage Books, 2011.

Hardin, G. "The Tragedy of the Commons." Science. vol. 162, 1968, pp. 1243-1248. doi:10.1126/science. 162.3859 .1243

Hayashi, M. "Japan's Fureai Kippu Time-banking in Elderly Care: Origins, Development, Challenges and Impact." International Journal of Community Currency Research, 16 Aug 2012, pp. 30-44. http://dx.doi. org/10.15133/j.ijccr.2012.003

Hayward, T. "Global justice and the distribution of natural resources." Political Studies (54), 2006, pp. 349-369.

IMF. "IMF Fiscal Monitor: Tackling Inequality, October 2017." International Monetary Fund. 2017, October. Retrieved from: http://www.imf.org/en/Publications/ FM/Issues/2017/10/05/fiscal-monitor-october-2017 International Forum of Sovereign Wealth Funds. IFSWF, 2018, http://www.ifswf.org.

Investopedia. "Sovereign Wealth Fund - SWF." Investopedia, 2018. Retrieved from: https://www.investopedia.com/ terms/s/sovereign_wealth_fund.asp

IPCC. Climate Change 2014: Synthesis Report. 2014. Retrieved from: https://www.ipcc.ch/pdf/assessmentreport/ar5/syr/SYR_AR5_FINAL_full_wcover.pdf

Jansen, T. R. "To Save on Rent, Some Dutch College Students Are Living in Nursing Homes." The Atlantic, 5 Oct 2015. Retrieved from: https://www.theatlantic. com/business/archive/2015/10/dutch-nursing-homecollegestudents/408976/

Kim, B. \& Belza, B. "Toward an Equitable Society for Every Generation." Journal of Gerontological Nursing, vol. 43, no. 11, 2017. doi:10.3928/00989134-20171012-01.

Lansley, S. "How Social Wealth Funds Could Help Tackle Inequality." The Political Quarterly (86.4) 2015, pp. 563-572.
Lennartz, C. \& Ronald, R. "Asset-based Welfare and Social Investment: Competing, Compatible, or Complementary Social Policy Strategies for the New Welfare State?" Housing, Theory and Society (34.2), 2017, pp. 201-220.

Lietaer, B. \& Dunne, J. Rethinking Money: How New Currencies Turn Scarcity into Prosperity. San Francisco: Berrett-Koehler Publishers, 2013.

"Making Money and Banking Work for Society." Positive Money, 2018. Retrieved from: http://positivemoney. org/

Mason, P. Postcapitalism: A Guide to Our Future. London: Allan Lane Publishers, 2016.

Mathys, Eric. Personal interview. 12 Dec 2017.

Marx, K. \& Engels, F. The Communist Manifesto. The Floating Press, 2009.

Marx, I. "Zou jij nog werken met een basisinkomen?" YouTube, uploaded by Universiteit van Vlaanderen, 23 Apr 2018, https://www.youtube.com/watch?v=Pu1tdoMk3Zg.

Mccann, D. "7 Principles for a Sovereign Wealth Fund." New Economics Foundation, 25 May 2017. Retrieved from: http://neweconomics.org/2017/05/7-principlessovereignwealthfund/

Middelkoop, W. Als de dollar valt. Alles over de kredietcrisis. Amsterdam: Nieuw Amsterdam, 2007.

More, T. Utopia. Translated by Adams, R. M. Cambridge: Cambridge University Press, 2016.

Nozick, R. Anarchy, State, and Utopia. New York: Basic Books, 1974.

OECD. "Ten Steps to Equality in Education." Organisation for Economic Co-operation and Development, Jan 2008. Retrieved from: https://www.oecd.org/education/ school/39989494.pdf Paine, T. Agrarian Justice. New York: Simon \& Schuster, 2013.

Paul, J. Thomas More. Cambridge: Polity Press, 2017.

Piketty, T. Capital in the Twenty-First Century. Translated by Arthur Goldhammer. London: The Belknap Press of Harvard University Press, 2014.

Plato, The Republic. Translated by Griffith. Cambridge: Cambridge University Press, 2000.

Pogge, T. "Eradicating Systemic Poverty: brief for a global resources dividend." Journal of Human Development (2.1), 2001, pp. 59-77.

Pohl, C. \& Hadron, G. H. "Methodological challenges of transdisciplinary research." Nature Sciences Sociétés, vol. 16, 2008, p. 111-121. doi: 10.1051/nss:2008035

Pohl, C., Krütli, P. \& Stauffacher, M. "Ten reflective steps for rendering research societally relevant." GAIAEcological Perspectives for Science and Society. 2017, 26(1), p. 43-51. Polis, H. (ed.) Utopisch Alfabet. Honderd toekomst visies. Antwerpen: De Bezige Bij, 2011. 
Ports, J., Reed, H., \& Percy, A. "Social Prosperity for the Future: A proposal for Universal Basic Services." Social Prosperity Network, Institute for Global Prosperity, 2017. Retrieved from: https://www.ucl.ac.uk/bartlett/ igp/sites/bartlett/files/universal_basic_services_the institu te_for_global_prosperity_.pdf

Rand, A. Capitalism: the Unknown Ideal. New York: Signet, 1967.

Rawlings, L., Sherburne-Benz, L. \& van Domelen, J. Evaluating Social Funds: a Cross-Country Analysis of Community Investments. Washington: The World Bank. 2004.

Rawls, J. A Theory of Justice. Harvard University Press, 1971.

Richard, M. "Norway fund blocked from private equity investment." Financial Times, 14 Apr 2018, p.11. Retrieved from: www.ft.com/content/2092083c-3cb511e8-b7e0-52972418fec4 Rifkin, J. The Zero Marginal Cost Society. New York: Saint Martin's Press, 2014.

Roberts, J. "Local action on health inequalities: Improving health literacy to reduce health inequalities." Public Health England, September 2015. Retrieved from: https://assets.publishing.service.gov.uk/government/ uploads/system/uploads/attachment_data/ file/460710/4b_Health_Literacy-Briefing.pdf

Rousseau, J. J. “Ideal Empires and Republics. Rousseau's Social Contract, More's Utopia, Bacon's New Atlantis, Campanella's City of the Sun." Washington: M. Walter Dunne. 1901. Sedlacek, T. Economics of good and evil. Oxford: Oxford University Press, 2011.

Sørensen, J. et al. "Health literacy and public health: A systematic review and integration of definitions and models." BMC Public Health, vol. 12, no. 1, 2012.

"Stichting Ons Geld." Ons Geld, 2018. Retrieved from: https://onsgeld.nu/over/ons

Sundararajan, A. "The Future of Work." International Monetary Fund. 2017. Retrieved from: http://www.imf. org/external/pubs/ft/fandd/2017/06/sundararajan.htm

Troncoso, S. "Universal Basic Services." Institute for Global Prosperity, 16 Feb 2018. Retrieved from: https://blog.p2pfoundation.net/universal-basicservices-could-work-better-thanbasicincome-tocombat-rise-of-the-robots/2018/02/16
UN. "Report on the World Social Situation 2011." United Nations Department of Economic and Social Affairs. 2011.

Vaidhyanathan, S. Intellectual Property: A Very Short Introduction. Oxford University Press, 2017.

van der Meer, T. W. G. "Political Trust and the "Crisis of Democracy"." Oxford Research Encyclopedia of Politics. 2017 Jan 25. Retrieved from: http://politics.oxfordre. com/view/10.1093/acrefore/9780190228637.001.0001/ acrefore978 0190228637-e-77

Van De Velde, Antoon. Personal interview. 14 Dec 2017.

Van Parijs, P. "Basic Income: A Simple and Powerful Idea for the Twenty-First Century." Politics \& Society. Sage Publications, vol. 32, no. 1, March 2004, pp. 7-39.

Van Parijs, P. Just Democracy: the Rawls-Machiavelli Programme. Colchester: ECPR Press, 2011.

Van Parijs, P. "Why Surfers Should be Fed: The Liberal Case for an Unconditional Basic Income." Philosophy and Public Affairs, vol. 20, no. 2, 1991, pp. 101-131.

Van Reybrouck, D. Against Elections: The Case for Democracy. Translated by Liz Waters. New York: Seven Stories Press, 2016.

Van Reybrouck, D. Tegen verkiezingen. Amsterdam/ Antwerpen: De Bezige bij, 2017.

Vande Moere, Andrew. Personal interview. 8 Dec 2017.

Varoufakis, Y. And the Weak Suffer What They Must?: Europe, Austerity and the Threat to Global Stability. London: The Bodley Head, 2016.

Walker, J. "The viable systems model: A guide for co-operatives and federations." ICOM, 1998. Retrieved from: http://www.scio.org.uk/resource/vsmg_3/pdf/ vsmg_2_2.pdf

"We Want to Democratize Money." International Movement for Monetary Reform. 2018. Retrieved from: https:// internationalmoneyreform.org/Zeddies, L. "Money Creation and Inequality An Underexposed Topic for Monetary Reformers." International Movement for Monetary Reform, 6 January 2018. Retrieved from: https://internationalmoneyreform.org/news/2018/01/ money-creation-inequalityunderexposed-topicmonetary-reformers/ 


\section{BANK OF TRANSDISCIPLINARY CHALLENGES}

\section{SECTION 1 OF 5 (BANK OF TRANSDISCIPLINARY CHALLENGES)}

Dear,

Welcome to the Bank of Transdisciplinary Challenges!

This is an initiative where people concerned about the future translate their concern into a scientific challenge. The challenge typically revolves around a specific society, environment, and/or business problem or opportunity that you want to be addressed by a transdisciplinary research team.

Are you concerned about a specific theme or topic for the future?

We invite you to be part of this initiative by filling out this form and sharing your challenge with our academic team and other stakeholders.

We will inform you if your challenge is taken up by our research team, and of any further activities. Hope to hear from you soon.

The Bank of Transdisciplinary Challenges.

\section{SECTION 2 OF 5 -BEFORE INFORMING US ABOUT YOUR CHALLENGE, WE WOULD LIKE TO KNOWABIT MORE ABOUT YOU.}

First Name: Kim

Last Name: Becher

E-mail Address: kb@shiftn.com

Affiliation:

$\square$ Academia as a Researcher

$\square$ Academia as a Student

$\square$ Government

囚 Industry

$\square$ Local Organization

$\square$ Non-profit Organization $\square$ Society

$\square$ Other:

If you are affiliated to an organization, please fill in its name here: shiftN You can also include some contact details of your organization. www.shiftn.com @shiftNGroup De Hoorn Creative Minds, Sluisstraat 79, 3000 Leuven Would you like to receive updates about this initiative? $\underline{\text { YES/NO }}$

\section{SECTION 3 OF 5 - ABOUT YOUR CHALLENGE-}

\section{ABOUT YOUR CHALLENGE}

\section{Name of the challenge:}

"Develop a systems map as a blueprint for a future, resilient and equitable society"

\section{Specific challenge:}

To produce a 'causal loop diagram' that shows how a new societal value creation model can be connected to a new social contract, including access to basic rights and the provision of new redistribution mechanisms. 


\section{Objectives:}

- To get a clear systemic view of the various obstacles (legal, architectural, economic, social, health care related) blocking the adoption of a new societal value creation model that would be more in line with the criteria of sustainability, social equity and community building than the current model.

- To get a clear systemic view of the (untapped) resources and possibilities (legal, architectural, economic, social, health care related) that would facilitate the creation of a new societal value creation model as described in the previous point, connecting it with a new social contract.

- Final objective: to build a causal loop model that visualizes the new societal model.

\section{Context and relevance to a transdisciplinary team:}

As shiftN, we often work in transdisciplinary settings. Our team brings in various disciplinary and methodological backgrounds, ranging from biology, philosophy, design, engineering to urban planning, psychology and organization development. In our assignments, we often deal with complex, 'wicked' problems, which demand multidisciplinary and transdisciplinary approaches. As part of our methodology, we invite scientists and stakeholders to think beyond the limits of their specialisms and integrate different ideas and perspectives into their thinking.

shiftN's interest in the topic of post-capitalism stems from our observation that the current late-capitalist system is unsustainable, not only from a monetary and economic point of view, but also from a social, environmental, cultural, psychological, medical and governance perspective.

Since the big credit crunch of 2008, no serious structural reforms have been undertaken to remedy the system's deficiencies. Governments have imposed austerity measures on their populations in order to save the banking system, but without taking the necessary steps to avoid a similar or worse kind of economic cataclysm in the future. In the meanwhile, many layers of society are suffering from the consequences of precarity and poverty. Public services are being cut down, inequality is mounting, trust in authorities and the political realm is eroding, populism and extremism are on the rise.

In the past, capitalism always found a way out of the big crises, mainly through technological innovation. However, as Paul Mason points out in his book "Postcapitalism", the information and network based technologies that have boomed over the last 25 years are not compatible with capitalism. Capitalism is based on scarcity, whereas infotechnologies are abundant by nature. They work best when they're free and shared.

With the advent of new information technologies, a different path has opened up: that of collaborative production. Goods, services and production methods are emerging that no longer fit into the logic of the market or managerial hierarchy. Developments like the shared economy, commons based peer production, cooperative currencies, all point towards a new paradigm, in which individual interests are tied to the common good and vertical hierarchies are being replaced by more open, horizontal types of collaboration. This not only requires different forms of organization, but also new ways of learning, creating, thinking and living.

Although collaborative structures are proliferating everywhere, there are still many obstacles preventing them to develop their full potential. Many legal and administrative provisions run counter to the fundamental principles and ethos of the cooperative economy, such as pay scales that are based on age or academic background.

In the decades following the $2^{\text {nd }}$ World War, a welfare state came into being in many Western countries, based on the creation and extension of social policies and social security structures. A social contract was agreed upon, based on 
the acceptance of capitalism as the ruling economic system in return for redistribution mechanisms that would guarantee the viability of the welfare system. The last decades have seen a gradual erosion of the welfare state under neoliberal rule. The time has come to think about a new social contract, which is more in sync with the value creating models of the New Economy.

One of the main questions regarding such a new social contract is whether it would continue to be based on the same old redistribution mechanisms. These are conceived as a compensation for labor and calculated on the basis of salary. But Info-technologies, however, reduce the need for work, blur the edges between work and free time, and loosen the relationship between work and wages (see Paul Mason, "Postcapitalism"). Could a Universal Basic Income be part of the solution?

\section{Relevance to a transdisciplinary team}

For this challenge, we would like the transdisciplinary team to think of how a new societal value creation model could be developed, taking a systemic view on the interaction between variables that are relevant to building such a model, including new legal frameworks ensuring social equity and wellbeing.

This challenge relates to various disciplines: architecture/urban planning, medicine, the cooperative economy, community building and new legal frameworks.

\section{The methodology}

The focus of the systems work in this challenge is to present an evidence-based, richly layered, qualitative model of a future, resilient and equitable society. We refer to this general approach as "systems thinking", and embodiment of this thinking in visual form as "systems mapping".

In order to further differentiate this work from other systems-oriented activities, we propose informal definitions of often-used terms such as system thinking, mapping and modelling:

"System thinking" refers to the activity of (more or less rigorously) using systems principles and systems-oriented heuristics in structuring our thinking about complex, problematic situations (examples of these are the System's Iceberg, Donella Meadows' Systemic Ladder, system dynamics archetypes and the notion of a system's root definition).

"Systems mapping" denotes the activity of working towards a coherent visual representation of a system.

"Systems modelling" aims at the construction of formal, quantitative models to obtain hopefully accurate predictions about a system's future state.

Qualitative systems maps do not have formal predictive power. They are used in a variety of ways in supporting sense-making and decision-making in complex environments:

As heuristic tool: to support meaningful conversation amongst experts and professionals; to invite new questions and hypotheses for data gathering and theory building.

As a knowledge management tool: to organise available knowledge in an integrative way.

As a diagnostic tool: to identify potential gaps in current policy approaches.

As an operational tool: to identify "leverage points" in the land system as a starting point for policy interventions.

The process of systems mapping can be structured in a number of phases: scoping, research, mapping, facilitation, communication and implementation. We suggest that the present challenge encompasses at least the first three phases. 


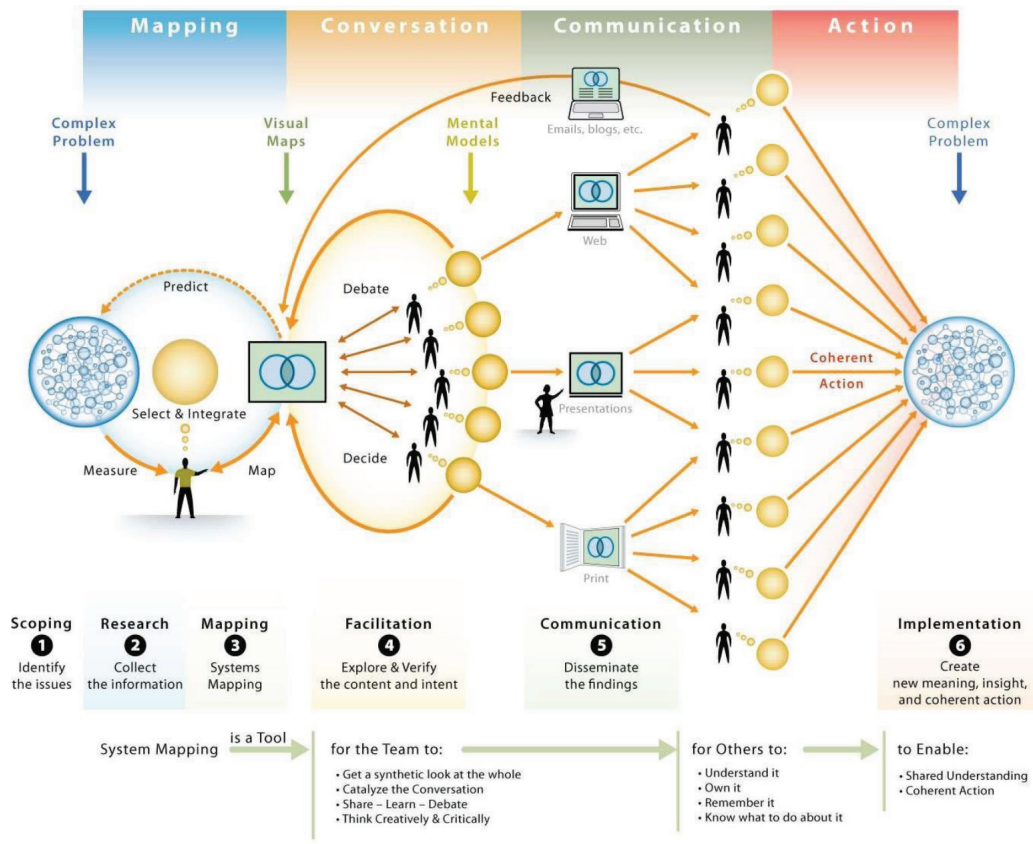

The transdisciplinary team for this project will be invited to participate for free in shiftN's systems mapping and Kumu course. shiftN will also seek to connect this challenge with our internal 'Beyond Capitalism' project and with other elements in the shiftN academy.

\section{Phasing of the research}

Phase I - We propose to start with a critical investigation of an embryonic ('core') systems model that shiftN (in collaboration with Namahn) developed in the framework of a recent assignment. The model is a very simple one that includes only a handful of variables. This is a back-of-the-envelope model that is not based on rigorous research. But it is a useful starting point for a systemic reflection. Research will focus on the nature of the variables included and the strength and validity of interconnections.

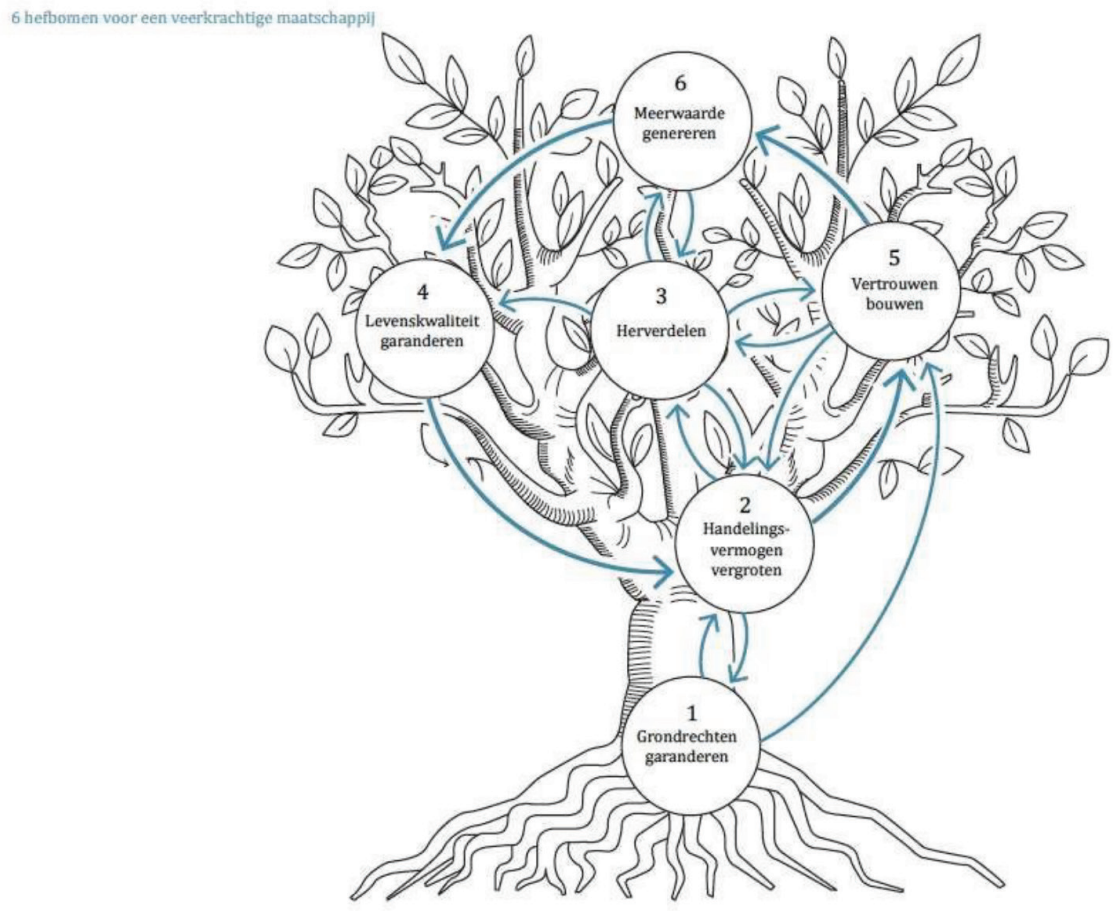


Phase II - As a result of this initial phase of research, the team will amend, expand the core model to a more encompassing model. The questions listed below (by discipline) may provide fruitful directions for research. The revised model will be implemented and documented in Kumu.

Phase III - The team will produce the desired deliverables (abstracts).

\section{Transdisciplinary context:}

Could you indicate from which disciplines you want a researcher to address this challenge, you need to pick at least one of each domain.

\section{Domain of Humanities and Social Sciences:}

$\square$ Arts

$\square$ Canon Law

囚 Economics and Business

凶Law

囚 Philosophy

$\square$ Psychology and Educational Sciences

囚 Social Sciences

$\square$ Theology and Religious Studies

Other:

\section{Domain of Science, Engineering and Technology:}

囚 Architecture

$\square$ Bioscience Engineering

Engineering Science

$\square$ Engineering Technology

Sciences

Other:

Domain of Biomedicine:

Kinesiology and Rehabilitation Sciences

冈 Medicine

Pharmaceutical Sciences

Other:

\section{Economics and business:}

- How can we foster the development of business models that are based on social and environmental responsibility and are centered around collaborative production? For example, 'reciprocity based licensing' is a model in which capital is not only granted to shareholders, but also to employees. This way, profits and power are distributed in a more equitable way (see Michel Bauwens from the P2P Foundation: 'Fair Shares').

- Could complementary currencies that link unmet societal needs to unused human potential be part of the solution? (See proposals from Bernard Lietaer). 
- Or what about an entire new monetary system, as proposed by Stichting Ons Geld (NL), Positive Money (UK) and Vollgeld-Initiative $(\mathrm{CH})$, which would reverse the roles of private banks and government and restore the privilege of money creation to the state.

- Could a universal basic income be a solution, as a first step to de-link salary from work and tackle the problem of unemployment in a highly automated society? (proposal by Paul Mason in his book 'Postcapitalism').

- One could take this even a step further and introduce a 'universal basic dividend', which wouldn't be financed by taxation, but through capital returns yielded by automation.

- What are the main obstacles that impede the upscaling and further development of the cooperative economy? Which available resources can be used to support it?

Law:

- Basic rights: should we guarantee a universal basic income to every citizen? Or a universal basic dividend? (see above).

- How can we assure the right to universal access to quality health care in the future? (See shiftN scenarios on drug pricing).

- Towards a new paradigm of freedom? Our current notion of freedom is heavily influenced by Roman Law: individual rights must be respected by others, but also involve the right to destroy one's own property. How does this match with social and environmental responsibility?

- What about intellectual property? Are IP-rights compatible with a collaborative economy and peer-to-peer production?

- Central Banks have a monopoly on money creation. They've used this monopoly in the past to abolish cooperative currencies, even though these currencies proved to be successful in tackling unemployment and social dislocation. Should this monopoly be challenged?

\section{Philosophy}

- Reflection on our current notions of autonomy, liberty and property: to what extent do they match with the notions of social and environmental responsibility and with conceptual frameworks of cooperative production, including notions as the commons, shared economy, open source, P2P?

- Our monetary system is based on scarcity and therefore stimulates competition rather than cooperation. On the other hand, oil pollution contributes to a higher BNP, whereas voluntary work to clean up the oil spill is not rewarded financially. What models of value creation can we create to contribute to a more sustainable and equitable solution?

- Could one think of a more horizontal, relational view of freedom, the possibility to enter into meaningful relationships with others and work together to create personal and social wellbeing?

\section{Social sciences}

- How can institutions of collective action (commons, initiatives from civil society) contribute to a new, more equitable and resilient societal model?

- Which models/theories in social sciences can be applied to enhance the cooperative economy?

- Which models/theories in social sciences can be used to enhance community building?

- Can examples from the past be used as an inspiration to new cooperative models?

\section{Medicine}

- How to promote an "ecological" view of medicine: recognizing the connections between the health of ecosystems, populations, communities and individuals?

- Which elements of the cooperative economy could contribute to a better access to health care, lower drug prices, better quality of care, community-based health care. 
- How to guarantee solidarity and access in the context of extremely expensive medicines, in particular for rare diseases? (See shiftN scenarios on drug pricing).

- Community health care: reflection on the strengths and weaknesses, opportunities and risks.E.g. can we speak of communities in urban contexts where neighbors don't know each other and communities are built along social, religious or racial lines? How can we tackle these issues?

\section{Architecture}

- Promoting ecological health in urban contexts, including composting, recycling, energy efficiency.

- Promoting urban agriculture to provide food, create green areas, create new jobs and strengthen the city's resilience to climate change.

- Improving access to everyone, in particular the poor and disabled.

Can we contact you for getting further details of your challenge? $\underline{\text { YES/NO }}$

Do you accept the terms and conditions for the proposition of this challenge? (See below) YES/NO

\section{Terms and Conditions}

1. Stakeholders (Students, University, Government, Industry, Society, and Non-profit Organizations) are invited to submit their challenges and also to share their insights to help address specific challenges, structured programs of analysis and knowledge sharing to address specific questions around societal or global problems faced by people and planet base on transdisciplinary interactions. This may be in the form of Stakeholders providing background for the challenge, publishing articles, posting comments in online discussions, participating in in-person events, or in other ways sharing their expertise.

2. If a submitted challenge is selected for further research, the academic team could modify the submitted contents for formatting in a scientific frame

3. Stakeholders should ensure that they own the intellectual property rights or have secured the necessary permissions to content or ideas they share as part of a Challenge

4. Intellectual property rights over content shared by a Stakeholder as part of a Challenge will remain with the original owner of the intellectual property.

5. Stakeholders that submit or contribute to a challenge will not be entitled to any payment or reward for contributing content to a challenge.

6. The intellectual property rights of final Challenge outputs, such as, but not limited to reports, papers, abstracts, videos, conferences, will belong solely to the "Transdisciplinary Insights Course" based on the Honors program regulated by the terms and conditions of the KU Leuven. These outputs will be made available in an open access "Transdisciplinary Insights e-Journal". Any other form of knowledge dissemination of the challenge output can be negotiated with the Academic team. Stakeholders agree that Challenge outputs can draw on content and ideas shared by them during the course of the Challenge, or shared on the "Transdisciplinary Insights e-Journal" or at a "Transdisciplinary Insights Course" -related event. Stakeholders agree to place no restrictions on the content that they share and grant permission to the "Transdisciplinary Insights e-Journal" to draw on or reproduce or publish this content, with appropriate attribution, in producing the Challenge outputs.

7. Challenges are funded by supporters. Supporters' names and/or logos will be acknowledged by the "Transdisciplinary Insights e-Journal"

8. "Transdisciplinary Insights Course" reserves the right to change or update these T\&Cs from time to time without prior notice to you.

Footnote: If your challenge involves a confidential agreement or if it requires corporate considerations, please contact: jorgericardo.novablanco@kuleuven.be 


\section{SECTION 4 OF 5 - SUPPORT, PARTNERS \& SHARING-}

How would you like to support that challenge?

$\bigotimes$ As a mentor, guiding one student in your specific discipline

$\square$ As an external expert in one of the fields.

$\square$ Financially.

$\square$ As a research coach, guiding a team around a specific challenge.

$\square$ Providing research facilities, equipment, samples, supplies, material ...

$\square$ Through taking part in the research discussion.

Other:

\section{Possible partners, experts and/or other stakeholders to involve in this challenge}

If you want your challenge to be dealt with not only by a transdisciplinary research group but also by stakeholders, could you please suggest stakeholders' name(s) to get involved in this research and if you have them, some contact details of each one?

The range of stakeholders affected by this challenge is potentially very large and encompasses all segments of society. We propose to provide the transdisciplinary team with access to a number of experts or resource persons who are able to contribute to a systemic reflection on broad societal transitions towards sustainability. These experts could be involved in personal interactions (via interviews, or team coaching sessions) or as a group (in a workshop format). To be decided.

\section{How can we introduce your challenge to other stakeholders?}

$\square$ By using your name.

By using your name and your affiliation

$\square$ By using only your affiliation

$\square$ Anonymously

\section{SECTION 5 OF 5 - THANK YOU FOR YOUR SUBMISSION AND SUPPORT.}

If you have questions about some parts of the process, please ask them here: 


\section{Blueprint for an Equitable and Resilient Society}

\section{Hinours}

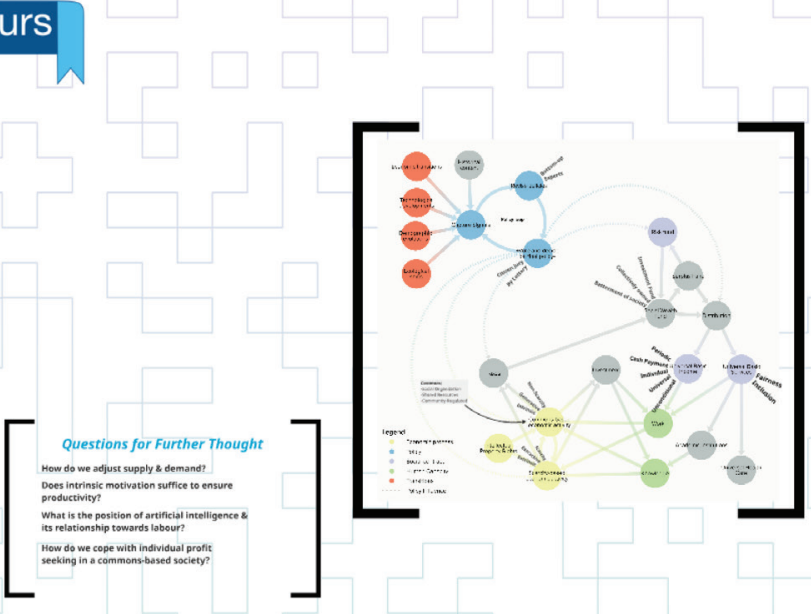

Thank you for your attention!

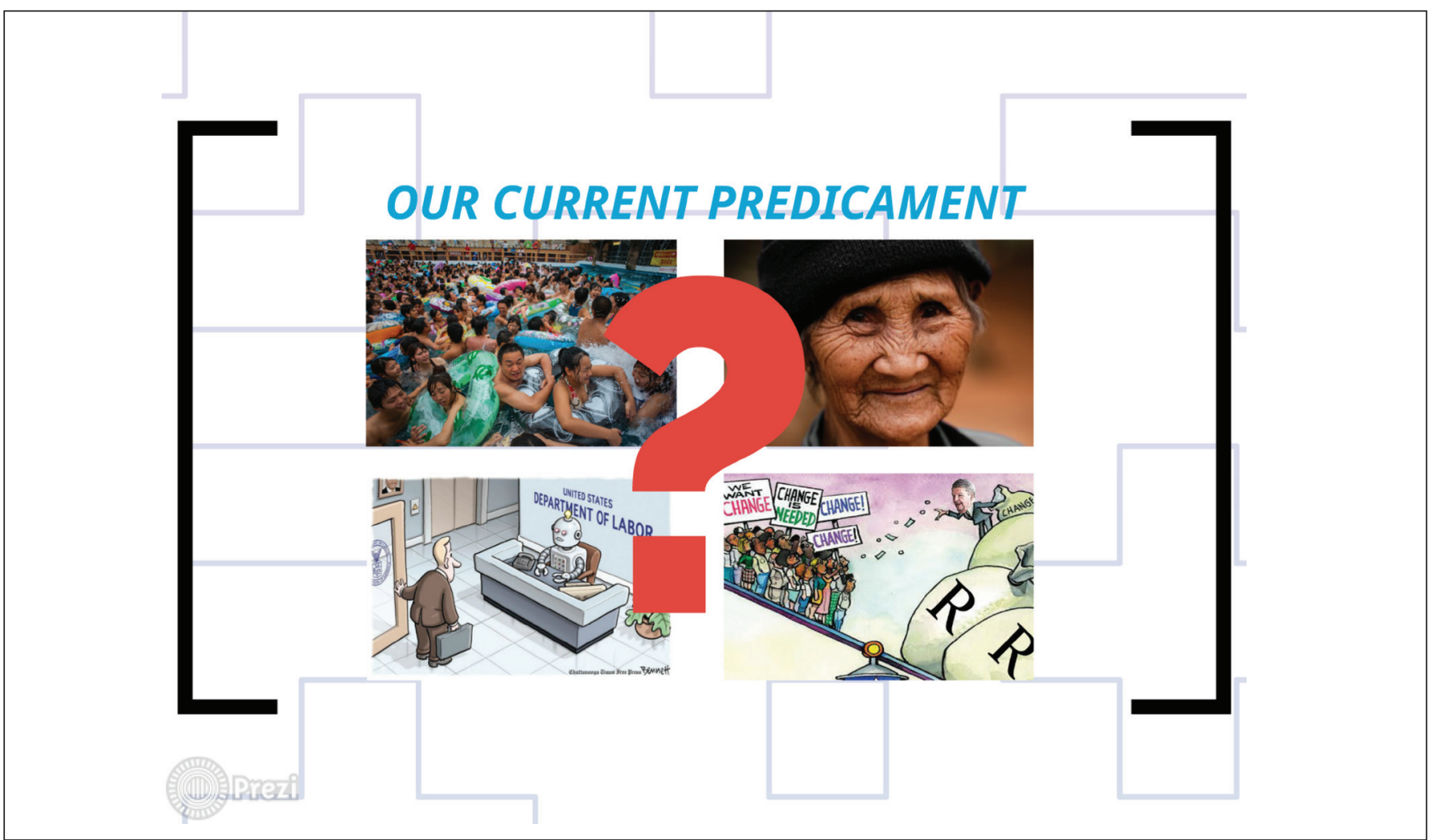



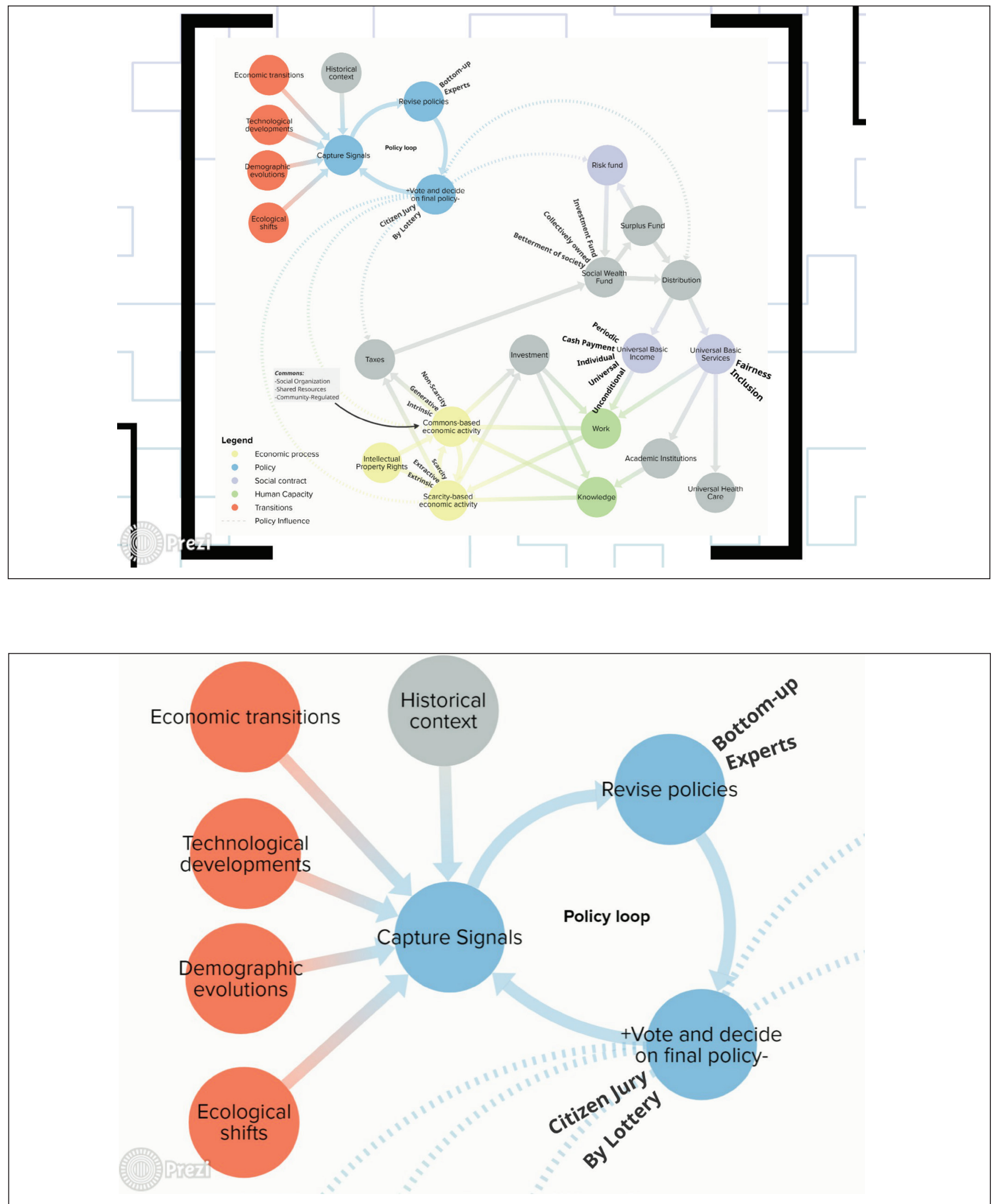

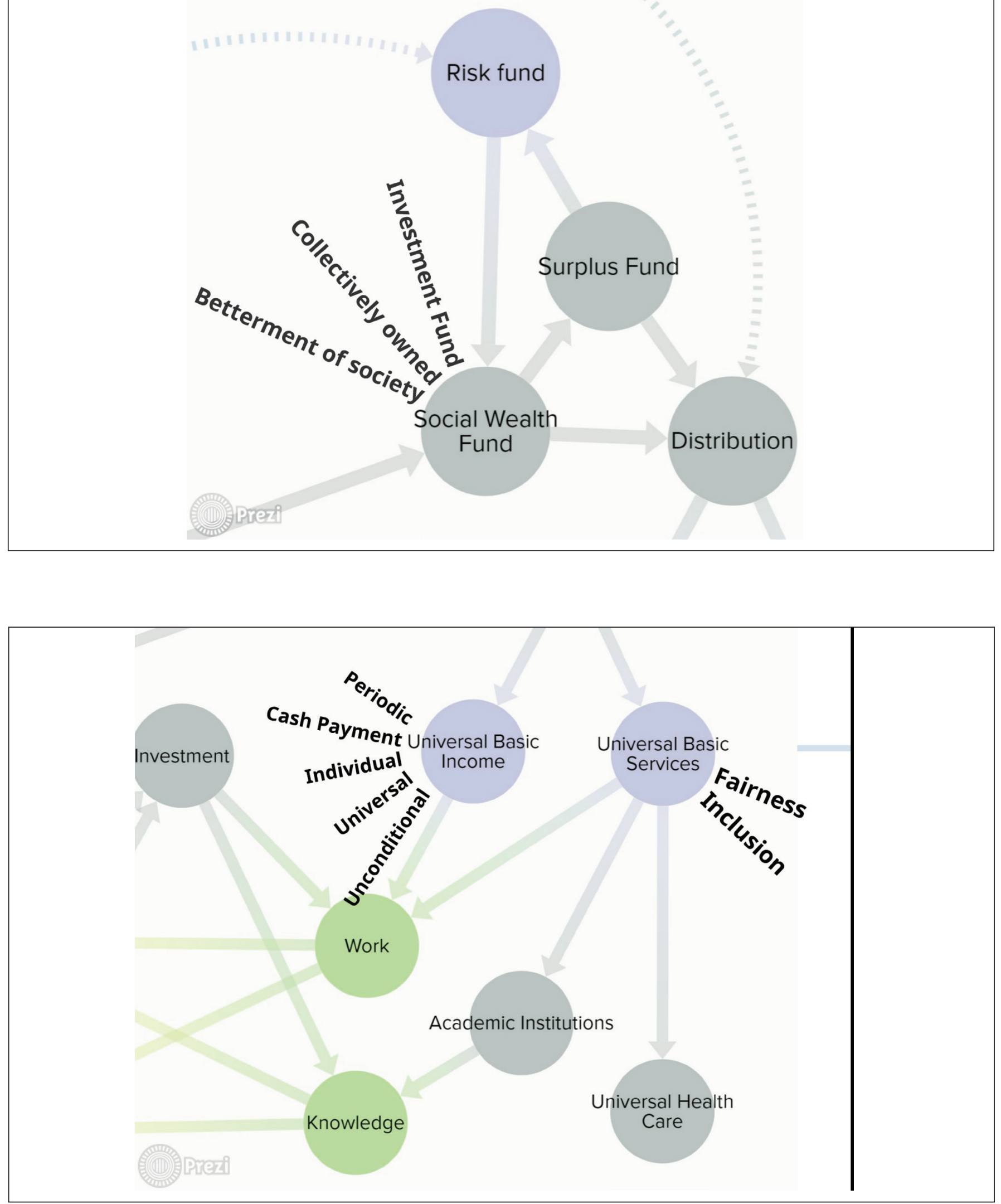


\section{Taxes}

\section{Commons:}

-Social Organization

-Shared Resources

-Community-Regulated

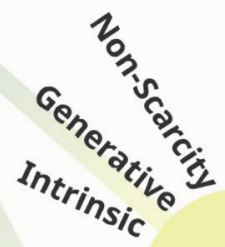

Commons-based

economic activity

\section{Legend}

Economic process

Policy

Social contract

Human Capacity

Transitions

Intellectual Property Rights

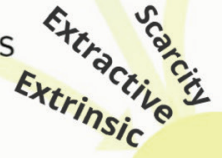

Scarcity-based economic activity

Policy Influence

\section{Questions for Further Thought}

How do we adjust supply \& demand?

Does intrinsic motivation suffice to ensure productivity?

What is the position of artificial intelligence \& its relationship towards labour?

How do we cope with individual profit seeking in a commons-based society? 


\section{Blueprint for an Equitable and Resilient Society}
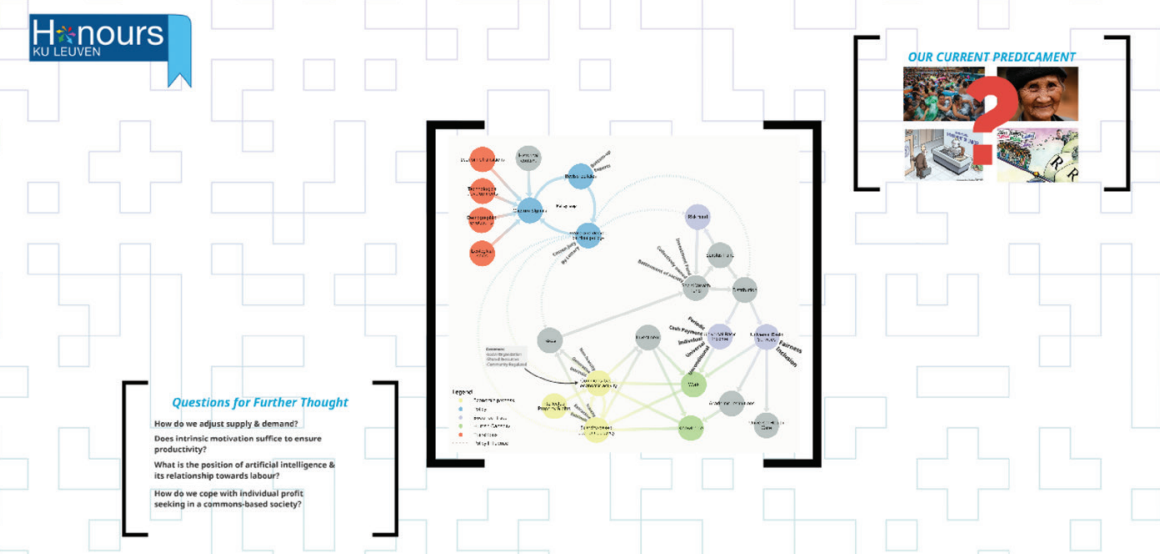

Thank you for your attention! 